\title{
Genetic structure and diversity of the selfing model grass Brachypodium stacei (Poaceae) in Western Mediterranean: out of the Iberian Peninsula and into the islands
}

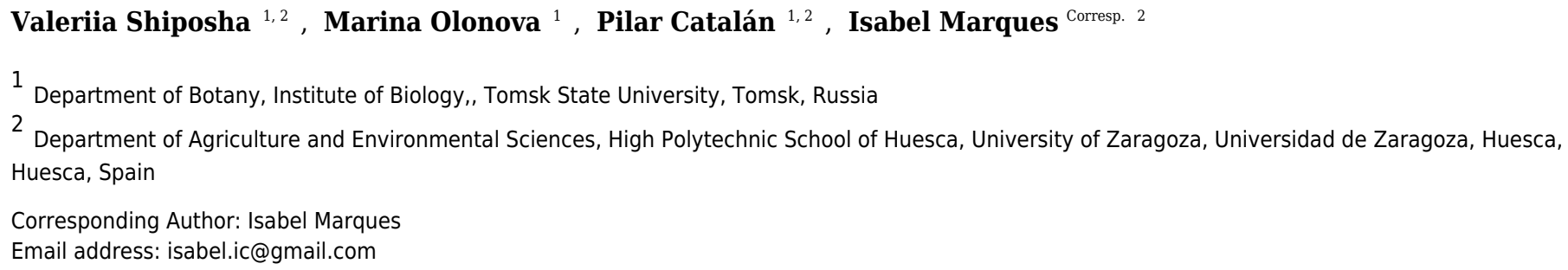

2 Department of Agriculture and Environmental Sciences, High Polytechnic School of Huesca, University of Zaragoza, Universidad de Zaragoza, Huesca, Huesca, Spain

Corresponding Author: Isabel Marques

Email address: isabel.ic@gmail.com

Annual Mediterranean species of the genus Brachypodium are promising model plants for energy crops since their selfing nature and short-life cycles are an advantage in breeding programs. The false brome, $B$. distachyon, has already been sequenced and new genomic initiatives have triggered the de-novo genome sequencing of its close relatives such as $B$. stacei, a species that was until recently mistaken for $B$. distachyon. However, the success of these initiatives hinges on detailed knowledge about the distribution of genetic variation within and among populations for the effective use of germplasm in a breeding program. Understanding population genetic diversity and genetic structure is also an important prerequisite for designing effective experimental populations for genomic wide studies. However, population genetic data are still limited in $B$. stacei. We therefore selected and amplified 10 nuclear microsatellite markers to depict patterns of population structure and genetic variation among 181 individuals from 19 populations of $B$. stacei occurring in its predominant range, the western Mediterranean area: mainland Iberian Peninsula, continental Balearic Islands and oceanic Canary Islands. Our genetic results support the occurrence of a predominant selfing system with extremely high levels of homozygosity across the analyzed populations. Despite the low level of genetic variation found, two different genetic clusters were retrieved, one clustering all SE Iberian mainland populations and the island of Minorca and another one grouping all S Iberian mainland populations, the Canary Islands and all Majorcan populations except one that clustered with the former group. These results, together with a high sharing of alleles (89\%) suggest different colonization routes from the mainland Iberian Peninsula into the islands. A recent colonization scenario could explain the relatively low levels of genetic diversity and low number of alleles found in the Canary Islands populations while older colonization events are hypothesized to explain the high genetic diversity values found in the Majorcan 
populations. Our study provides widely applicable information about geographical patterns of genetic variation in B. stacei. Among others, the genetic pattern and the existence of local alleles will need to be adequately reflected in the germplasm collection of $B$. stacei for efficient genome wide association studies. 
1 Genetic structure and diversity of the selfing model grass

2 Brachypodium stacei (Poaceae) in Western Mediterranean: out of

3 the Iberian Peninsula and into the islands

4

5 Valeriia Shiposha ${ }^{1,2}$, Marina Olonova ${ }^{2}$, Pilar Catalán ${ }^{1,2}$, Isabel Marques, ${ }^{1, *}$

6

7 1. Department of Agriculture and Environmental Sciences, High Polytechnic School of Huesca,

8 University of Zaragoza, Ctra. Cuarte km 1, 22071 Huesca, Spain.

9 2. Department of Botany, Institute of Biology, Tomsk State University, Lenin Av. 36, Tomsk

10634050, Russia.

11 *Corresponding author: isabel.ic@gmail.com 


\section{Abstract}

14 Annual Mediterranean species of the genus Brachypodium are promising model plants for energy crops since their selfing nature and short-life cycles are an advantage in breeding programs. The false brome, $B$. distachyon, has already been sequenced and new genomic initiatives have triggered the de-novo genome sequencing of its close relatives such as $B$. stacei, a species that was until recently mistaken for $B$. distachyon. However, the success of these initiatives hinges on detailed knowledge about the distribution of genetic variation within and among populations for the effective use of germplasm in a breeding program. Understanding population genetic diversity and genetic structure is also an important prerequisite for designing effective experimental populations for genomic wide studies. However, population genetic data are still limited in B. stacei. We therefore selected and amplified 10 nuclear microsatellite markers to depict patterns of population structure and genetic variation among 181 individuals from 19 populations of $B$. stacei occurring in its predominant range, the western Mediterranean area: mainland Iberian Peninsula, continental Balearic Islands and oceanic Canary Islands. Our genetic results support the occurrence of a predominant selfing system with extremely high levels of homozygosity across the analyzed populations. Despite the low level of genetic variation found, two different genetic clusters were retrieved, one clustering all SE Iberian mainland populations and the island of Minorca and another one grouping all S Iberian mainland populations, the Canary Islands and all Majorcan populations except one that clustered with the former group.

32 These results, together with a high sharing of alleles (89\%) suggest different colonization routes from the mainland Iberian Peninsula into the islands. A recent colonization scenario could explain the relatively low levels of genetic diversity and low number of alleles found in the

35 Canary Islands populations while older colonization events are hypothesized to explain the high 
36 genetic diversity values found in the Majorcan populations. Our study provides widely

37 applicable information about geographical patterns of genetic variation in B. stacei. Among

38 others, the genetic pattern and the existence of local alleles will need to be adequately reflected

39 in the germplasm collection of B. stacei for efficient genome wide association studies.

40

41

42

43 Running title: Genetic diversity in Brachypodium stacei 
44

45

46

47

48

49

50

51

52

\section{Introduction}

Approximately one third of Earth's land is covered by grass-dominated ecosystems comprising 600 genera and more than 12,000 species (Soreng et al. 2015). Besides their important ecological role, grasses are the core of human nutrition and several genomic efforts have focused on economically important species (e. g., rice: International Rice Genome Sequencing Project, 2005; sorghum: Paterson et al. 2009). Among grasses, the genus Brachypodium, a member of the Pooideae subfamily, has recently been developed as a new model system to study the evolution of grasses. The genome of the annual $B$. distachyon, commonly known as the false brome, has already been sequenced (IBI 2010). This species has several features suitable for the development of a model plant for genomic studies such as a small diploid genome ( $355 \mathrm{Mbp})$, a short annual life-cycle, easily amenable to culture, and a selfing nature (Gordon et al. 2014). The taxonomic identity of $B$. distachyon was recently challenged with the recognition that the three cytotypes attributed to different ploidy levels in this species (e. g., an autopolyploid series of individuals with $\mathrm{x}=5$ and $2 \mathrm{n}=10(2 \mathrm{x}), 20(4 \mathrm{x}), 30(6 \mathrm{x})$ chromosomes; Robertson 1981) were in fact three different species: two diploids, each with a different chromosome base number, $B$. distachyon $(\mathrm{x}=5,2 \mathrm{n}=10)$ and $B$. stacei $(\mathrm{x}=10,2 \mathrm{n}=20)$, and their derived allotetraploid B. hybridum (x = 5+10, 2n = 30) (Catalán et al. 2012; López-Alvarez et al. 2012). This recent taxonomic split has triggered new genomic initiatives including the re-sequencing of 56 new accessions of $B$. distachyon and the de-novo genome sequencing of $B$. stace $i$ and $B$. hybridum, a project undertaken by the Joint Genome Institute and the International Brachypodium Consortium (http://brachypodium.pw.usda.gov/files/resequencing_description_110822.pdf). The forthcoming genomes of $B$. stacei and B. hybridum will allow the development of several functional genomic 
67 analyses on these diploid and polyploid species and their potential transfer to other cereals and

68

69

forage or biofuel crops. A recent update on phenotypic traits and habitat preferences of the three species has increased the number of discriminant features that distinguish them and has thrown new insights into their respective ecological adaptations (Catalán et al. 2016a). However, very scarce genetic information exists for these close relatives of B. distachyon, especially for the rarest species of this complex, B. stacei (Catalán et al. 2016b). It would, therefore, be invaluable to have more information especially because a collection of germplasm reflecting the natural diversity of $B$. stacei is necessary for future genome wide association studies and the creation of reference lines.

Brachypodium stacei is a monophyletic annual diploid species that diverged first from the common Brachypodium ancestor, followed consecutively by B. mexicanum, B. distachyon and the clade of the core perennial taxa (Catalán et al. 2012; Catalán et al. 2016b). Several studies have revealed it to be distinct from B. distachyon and B. hybridum: e. g., protein data: Hammami et al. 2011; nuclear SSRs: Giraldo et al. 2012; DNA barcoding: López-Alvarez et al. 2012; isozymes: Jaaska 2014. A recent study using environmental niche models predicted a potential distribution of B. stacei in coastal and lowland areas of the circum-Mediterranean region (LópezAlvarez et al. 2015), concurrent with its known geographic distribution (Catalán et al. 2016a). However, a large number of those populations occur in the western Mediterranean region and in Macaronesia (López-Alvarez et al. 2015; Catalán et al. 2016a). Population genetic studies conducted in its annual congener $B$. distachyon have demonstrated that the genetic structure does not fit a geographic pattern but rather might have resulted from a combination of factors such as long distance dispersal of seeds and flowering time isolation (Vogel et al. 2009; Mur et al. 2011; Tyler et al. 2016). 
the western island populations (continental Balearic Islands and oceanic Canary Islands) of $B$.

92 stacei to unravel the origin and phylogeographic patterns of its populations. From all its range, this area is the best known due to previous studies (Catalán et al. 2012, 2016a; López-Alvarez et al. 2012, 2015), which can guarantee the correct identification of $B$. stacei since it can be misidentified with its close-relatives (López-Alvarez et al. 2012). We specifically addressed the following questions: (1) Is genotypic diversity within populations limited by the prevalence of autogamous pollinations? (2) Do islands (e. g., continental, oceanic) contain less genetic variation than mainland areas? (3) Is there a signature of geographic genetic structure in this selfpollinated plant? Finally, we aim to provide recommendations necessary to establish an efficient germplasm collection of $B$. stacei, with the aim of helping future genomic initiatives in Brachypodium.

\section{Material and methods}

\section{Population sampling, DNA extraction and nSSR amplification}

A total of 181 individuals were sampled from 19 populations of $B$. stacei covering the whole distribution range of this species within the Iberia Peninsula, plus the continental Balearic (Gymnesic) Islands (Majorca, Minorca) and the oceanic Canary Islands (Gomera, Lanzarote) (Table 1; Fig. 1). Nine populations were sampled in mainland Iberian Peninsula and ten across the two groups of islands (Fig. 1). In each population, ten individuals were collected randomly with a minimum sampling distance of $10 \mathrm{~m}$, with the exception of the Iberian ALI and the Majorcan BANYA populations where only five and six individuals were respectively found. Sampling sizes, locations and geographic coordinates of each population sampled are given in 
113 Table 1. Fresh leaves were collected for each individual, dried in silica gel and stored at $-20^{\circ} \mathrm{C}$

114 until ready for DNA isolation. The silica samples for all individuals were deposited in the DNA

115 bank of the BioFlora group at the University of Zaragoza in Spain and voucher specimens were

116 deposited in the JACA herbarium (Spain).

117 Total genomic DNA was extracted from fresh leaf tissue or from silica-dried leaf samples

118 using the DNeasy Plant Mini Kit (Qiagen, Valencia, CA, USA) according to the manufacturer's

119 protocol. The 181 samples used in this study were genotyped at 10 variable nuclear

120 microsatellite markers (nSSRs) developed for B. distachyon (ALB006, ALB022, ALB040,

121 ALB050, ALB086, ALB087, ALB139, ALB165, ALB181 and ALB311; Vogel et al. 2009). All

122 those microsatellites were selected because during our preliminary studies they displayed good

123 quality and high transferability success in B. stacei. The forward primer of each locus was 5-end

124 labeled with a fluorescent dye. Amplifications were carried out in a final volume of $10 \mu 1$

125 volumes containing between 0.1 and $0.2 \mu \mathrm{l}$ of each $10 \mathrm{M}$ diluted primer (forward and reverse), $5 \mu \mathrm{l}$

126 PCR Master Mix (QIAGEN) and 2.5 $\mu$ l DNA. The polymerase chain reactions (PCR) were

127 carried out in a final volume of $7.5 \mu \mathrm{l}$ on a GeneAmp PCR System 9700 thermocycler with a

128 thermal profile consisting of a 4-min initial denaturation step at $95^{\circ} \mathrm{C}$ followed by 35 cycles of

$12930 \mathrm{~s}$ at $95^{\circ} \mathrm{C}, 30 \mathrm{~s}$ at $55^{\circ} \mathrm{C}$ and $1 \mathrm{~min}$ at $72^{\circ} \mathrm{C}$. A final $72^{\circ} \mathrm{C}$ extension step of 30 min was

130 included to promote non-templated nucleotide addition at the 3 'end of the PCR product.

131 Multiplexed PCR products were genotyped on an Applied Biosystems 3130XL Genetic Analyzer

132 using $2 \mu \mathrm{l}$ of amplified DNA, $12 \mu \mathrm{l}$ of Hi-Di formamide and $0.4 \mu \mathrm{l}$ of GeneScan-500 (LIZ) size

133 standard (Applied Biosystem). Allele sizes were determined using Peak Scanner version 1.0

134 (Life Technologies). Within each population, all loci were checked for the presence of null

135 alleles using MICRO-CHECKER v.2.2.3 (Van Oosterhout et al. 2004) 
137 Hardy-Weinberg equilibrium, linkage disequilibrium and genetic diversity

138 Deviation from Hardy-Weinberg Equilibrium (HWE) was tested at both population and locus

139 levels using FSTAT 2.9.3.2 (Goudet 2001). To calculate the extent of linkage disequilibrium

140 between pairs of loci (LD) in each population we set dememorization numbers at 10000 and

141 performed 100000 iterations for all permutation tests (exact tests) in Genepop v.4.0.10

142 (Raymond and Rousset 1995). Significant values were corrected for multiple comparisons by

143 Bonferroni correction (Rice 1989).

144 For each microsatellite locus and population, genetic polymorphism was assessed by

calculating the total number of alleles ( $\mathrm{Na}$, allelic diversity), mean expected heterozygosity $(\mathrm{He})$, mean observed heterozygosity $(\mathrm{Ho})$, allelic richness $\left(A_{R}\right)$, and inbreeding coefficient $\left(F_{\mathrm{IS}}\right)$ using FSTAT 2.9.3.2 (Goudet 2001). The inbreeding coefficient was also estimated using the Bayesian procedure (IIM) implemented in INEst 2.0, which is robust to the presence of null alleles

149 (Chybicki and Burczyk 2009). Posterior distribution was based on 300,000 steps, sampling every 100 steps and discarding the first 30,000 steps as burn-in. In order to infer the statistical significance of inbreeding we compared the full model (nfb), the model including only the possibility of null alleles and inbreeding (nf), and the model including only null alleles and genotyping failures (nb). The best model was chosen based on the Deviance Information

154 Criterion (DIC; cf. Chybicki et al. 2011).

GenAlEx 6 software was used to estimate the mean expected heterozygosity $(\mathrm{He})$ and 156 mean observed heterozygosity $(\mathrm{Ho})$ for each population (Peakall and Smouse, 2006). In addition,

157 the selfing rate $(s)$ was also estimated as $\mathrm{s}=2 F_{\mathrm{IS}} /\left(1+F_{\mathrm{IS}}\right)$ (Ritland 1990). Spatial patterns of 158 allelic quantity were visualized by mapping variation for the locations across space with the 
159 interpolation kriging function in ARCINFO (ESRI, Redlands, CA, USA), using a spherical 160 semivariogram model.

161

162 Population genetic structure, genetic differentiation and isolation

163 The Bayesian program STRUCTURE v.2.3.4 (Pritchard et al. 2000a) was used to infer the

164 population structure and to assign individual plants to subpopulations. Models with a putative

165 numbers of populations $(K)$ from 1 to 10 , imposing ancestral admixture and correlated allele

166 frequencies priors, were considered. Ten independent runs with 50000 burn-in steps, followed

167 by run lengths of 300000 interactions for each $K$, were computed. The number of true clusters in

168 the data was estimated using STRUCTURE HARVESTER (Earl 2012), which identifies the

169 optimal $K$ based both on the posterior probability of the data for a given $\mathrm{K}$ and the $\Delta \mathrm{K}$ (Evanno

170 et al. 2005). To correctly assess the membership proportions ( $q$ values) for clusters identified in

171 STRUCTURE, the results of the replicates at the best fit $K$ were post-processed using CLUMPP

172 1.1.2 (Jakobsson \& Rosenberg 2007). BAPS v.5.2 (Corander et al. 2006) was used to explore

173 population structure further. In contrast to STRUCTURE, BAPS determines optimal partitions

174 for each candidate $K$-value and merges the results according the log-likelihood values to

175 determine the best $K$-value. Analyses in BAPS were done at the level group of individuals using

176 the models without spatial information and by selecting 1 to 10 as possible $K$-values. Ten

177 repetitions were performed for each $K$. POPULATION 1.2 (Langella 2000) was used to calculate

178 the Nei's genetic distance $\left(\mathrm{D}_{A}\right.$; Nei 1983) among individuals and to construct an unrooted

179 neighbor-joining tree with 1000 bootstrap replicates. Nei's genetic distance among individuals

180 was also visualized by Principal Components Analysis (PCoA) with GenAlEx6 (Peakall \&

181 Smouse 2006). 

variance (AMOVA) with ARLEQUIN 3.11 (Excoffier et al. 1992). In addition, molecular variance was also studied (1) between the genetic groups retrieved by STRUCTURE and BAPS, variance was quantified among groups, among locations within groups and within sampling locations. Each AMOVA was run with 10000 permutations at 0.95 significance levels.

Relationships between genetic and linear geographic distances (isolation-by-distance, IBD) were examined using a Mantel test (Mantel 1967) implemented in GENEPOP 3.3 (Raymond \& Rousset 1995) with 10000 permutations.

\section{Results}

\section{Hardy-Weinberg disequilibrium, non linkage disequilibrium}

195

Deviations from HWE were common in the selfed B. stacei. From the 19 populations sampled, only five were at HWE (GRA, MEN, ARTA, FELEN, GOM) at the 5\% level after the sequential Bonferroni correction (Table 2). Pairwise comparisons between loci revealed no significant linkage disequilibrium at the $P=5 \%$ suggesting that alleles are assorting independently at different loci.

\section{Genetic diversity and mating system of Brachypodium stacei}

For each locus, observed heterozygosity values ranged from 0 to 0.058 (respectively for loci $A L B 139$ and $A L B 086$ ), and expected heterozygosity ranged from 0 to 0.145 (respectively for loci $A L B 139$ and $A L B 087$ ). $\mathrm{F}_{\text {IS }}$ values varied between -0.068 and 0.8482 (respectively for loci 
205

206

207

208

209

210

211

212

213

214

215

216

217

218

219

220

221

222

223

224

225

226

ALB311 and ALB022; Table 3) across the loci studied. No null alleles were detected. The results from the Bayesian analyses implemented in INEst revealed that only inbreeding contributed to the excessive homozogosity, since this model ( $\left.\mathrm{DIC}_{\mathrm{nf}}: 3300.019\right)$ was preferred over the alternative ones $\left(\mathrm{DIC}_{\mathrm{nfb}}: 4400.390\right.$; $\left.\mathrm{DIC}_{\mathrm{nb}}: 4400.300\right)$ based on the DIC criterion.

From the 19 sampled populations of $B$. stacei, only 37 distinct alleles were found in the 181 individuals studied (Fig. 2; Table S1). Most of the alleles (27 alleles; 73\%) were shared between populations while the remaining ones were private to mainland, Majorca, Minorca or the Canary Islands (10 alleles; 27\%). Most of the alleles found in the islands were also found in the mainland since only 3 alleles out of $27(11 \%)$ were not found in the mainland: 2 alleles were shared between Majorca and Minorca and 1 allele was shared between Majorca and the Canary Islands (Fig. 2). Out of 37, four alleles were exclusively found only in the mainland (10\%; 3 in SE Spain and 1 in S Spain), six in Majorca (16\%) and one in Minorca (2\%) while the Canary Islands had no unique alleles (Fig. 2).

The number of alleles generally increased in the Balearic Islands, most specially in Majorca $(P<0.0001)$ as shown when projected into the geographic space (Fig. 3). Overall, only $38 \%$ (69 out of 181) of all genotyped samples exhibited unique multi-locus genotypes, as a consequence of the rampant homozygosis (fixed alleles) observed for most loci in most populations. The observed percentage is lower than one might expect under random mating, where the frequency of multilocus genotypes is expected to be equal to the product of the allelic frequencies. However, a relatively high number of unique multi-locus genotypes were generally found in the populations collected in the island of Majorca, where up to $100 \%$ of all the individuals sampled showed unique multi-locus genotypes (Table 1). 
228 (mainland population CALBA) and 0.290 (Majorcan population BONA) with a CI of \pm 0.03 at

229 the 95\% level, while mean expected heterozygosity varied between 0.090 (mainland population

230 CALREL) and 0.239 (Majorcan population BANYA; Table 1) with a CI of \pm 0.04 at the $95 \%$

231 level. The average $F_{\text {IS }}$ value was 0.558 (CI: 0.141 ) varying between 0.0001 (mainland population

232 ALM, Majorcan population ALCU) and 1 (Canary population of LAN). Therefore, the average

233 rate of self-fertilization in $B$. stacei was estimated to be $71 \%$ considering all the populations

234 (Table 1). However, the wide range of $F_{\text {IS }}$ values implies that the predicted level of self-

235 fertilization also varies extensively across populations with a CI of \pm 0.25 at the $95 \%$ level.

\section{Population genetic structure among geographical areas}

238 The Bayesian clustering program STRUCTURE found the highest LnP(D) and $\Delta \mathrm{K}$ values for $K=2(P<0.001)$ which differentiated all south $(\mathrm{S})$ Iberian mainland populations from the southeastern (SE) mainland populations. The populations collected in the island of Minorca clustered with the SE mainland populations, whereas samples from the Canary Islands and most of the Majorcan populations were grouped with the S mainland populations, with the exception of the Majorcan population of BONA were most individuals were assigned to the same genetic group found only in the SE mainland populations (Fig. 4a). Some individuals collected in four populations of Majorca showed genetic admixture between the two genetic groups (DRAG, CAMPA, ALCU, BONA; Fig. 4a). These results were also corroborated by BAPS, which retrieved similar results and generally differentiated S mainland populations, Canary Islands and 
251 from all remaining populations at both extremes of axis I, which accumulated $44.3 \%$ of variance

252 (Fig. 5), partially supporting the genetic boundaries assigned by STRUCTURE and BAPS at

$253 K=2$. In this two-dimensional plot, the $\mathrm{S}$ mainland populations, as well as the SE ones and the

254 Island populations (Minorca, Majorca and the Canary Islands) were well differentiated along the

255 axis 2 , which accumulated $26.2 \%$ of variance.

256 The NJ tree separated all SE mainland populations, Minorca and the Majorcan population

257 of BONA from the remaining populations, in a highly supported group (78\% bootstrap support

258 (BS) value; Fig. 6a). A similar NJ tree was retrieved when the admixed individuals indicated by

259 STRUCTURE were excluded (Fig. 6b). The remaining sub-divisions found in the NJ trees

260 correspond mainly to the populations sampled although BS values were always very low, with or

261 without admixed individuals (<43\%, Fig. 6a-b).

\section{Genetic differentiation and isolation}

264 Overall, genetic differentiation was significantly high (AMOVA FST $=0.748, P<0.00001$ ). The analysis performed over the 19 populations sampled indicated that $75 \%$ and $25 \%$ of the genetic variation was attributed to variation among and within populations, respectively $(P<0.00001$; populations within groups and within populations (Table 4). Fixation indices of this analysis were $\mathrm{FST}=0.779, \mathrm{FSC}=0.710$ and $\mathrm{FCT}=0.240 . \quad$ To further investigate genetic differentiation

271 between mainland and island populations, an independent AMOVA also attributed the highest

272 percentage of variation among populations within groups $(68 \%$ of the total variance; $\mathrm{FST}=0.758$, 
$273 \mathrm{FSC}=0.737$ and $\mathrm{FCT}=0.077$; Table 4 ). However, genetic variation was equally partitioned among

274 groups, among populations within groups and within groups when analyzing only island

275 populations $(\mathrm{FST}=0.672, \mathrm{FSC}=0.516$ and $\mathrm{FCT}=0.322)$, and predominant among groups and

276 among populations within groups when analyzing only mainland populations ( $\mathrm{FST}=0.884$,

$277 \quad \mathrm{FSC}=0.783$ and $\mathrm{FCT}=0.464$; Table 4).

278 The Mantel's test did not detect any significant correlation between the genetic distance

$279\left[\mathrm{~F}_{\mathrm{ST}} /\left(1-\mathrm{F}_{\mathrm{ST}}\right)\right]$ and the geographical distance of the populations studied here $\left(r^{2}=0.83, y=1.755 x\right.$ $280 \quad 0.223, P=0.085)$.

\section{Discussion}

283

284

285

286

287

\section{Incidence of a highly selfing mating system}

From our genetic study, selfing rates of $B$. stace $i$ were estimated as $79 \%$ across all populations, even reaching values as high as $95 \%$ in some populations (Table 1) although CI values were fairly wide. Even if null alleles have not been detected, the high variation occurring between loci for many of the genetic parameters estimated (Table 3) might influence the reported genetic values. Nonetheless, there was clearly a predominance of homozygous individuals, suggesting that B. stacei is primarily a selfing species like its close congener B. distachyon (Draper et al. 2001; Gordon et al. 2014). Although the respective ancestors of these two annual species likely split 16.2 (B. stacei) and 10.2 (B. distachyon) Mya ago (cf. Catalán et al. 2016b), species divergence was not followed by changes in the mating system of B. distachyon and B. stacei. This analogous mating system is consistent with similarities in floral morphology and floral structure in the two species since they both bear relatively small (mean 7-9 $\mathrm{mm}$ ) cleistogamous or cleistogamous-type florets having minute $(<0.8 \mathrm{~mm})$ non-exerted anthers (Catalán et al. 
296 2016a). Pollination in B. distachyon usually occurs in closed flowers leading to extremely high

297 levels of homozygosity (Vogel et al. 2009), such as the ones reported here for B. stacei. Even

298 more recently diverged species, such as the perennial B. sylvaticum, display a predominantly

299 selfing system, although the levels of heterozygosity suggest that this species outcross more

300 often than B. distachyon and B. stacei (Steinwand et al. 2013).

301 In nature, selfing is thought to be favored due to its inherent transmission advantage, as

302 well as assuring reproduction when pollinators or available mates are scarce (Marques et al.

303 2014) and it is expected to evolve whenever these advantages outweigh the costs of inbreeding

304 depression (Charlesworth \& Willis 2009). But contrary to these short-term benefits, selfing

305 might also reduce effective recombination rate leading to frequent genetic bottlenecks (Goldberg

306 et al. 2010). Recombination is generally thought to be advantageous because it breaks down

307 associations between alleles (linkage disequilibrium), which might lead to the fixation of

308 deleterious mutations (Charlesworth and Charlesworth 2000). As a result, it has long been

309 argued that the evolutionary potential of highly selfing species is quite limited as a result of

310 reduced genetic diversity and recombination rates (Lynch et al. 1995). However, many important

311 crops such as wheat, barley, beans, and tomatoes, are predominantly self-fertilizing species

312 despite the possibility of linkage drag (Morrell et al. 2004). Likewise, linkage disequilibrium is

313 absent in B. stacei despite being a highly selfing species. There are several possible explanations.

314 The first is that the relatively low levels of linkage disequilibrium results from a recent transition

315 from a strict outcrossing ancestral mating system to a predominantly selfing one, so that the

316 recombination events would still be present (Lin et al. 2001). However, recent phylogenetic

317 studies indicated that B. stacei is the earliest extant diverging lineage within the genus and that

318 other early splits also resulted in selfing species (e. g., B. mexicanum; Catalan et al. 2016b). The 
319 second possible explanation is that in a temporal time scale of more than 38 Mya to the common

320 ancestor of the Brachypodium stem node (e. g. MRCA of the Brachypodieae/core pooids split;

321 Catalán et al. 2016b), even a very low number of outcrossing events might be enough to promote

322 a certain level of recombination. Although plant species might usually mate through selfing, few

323 are strictly selfing (Igic and Busch 2013), creating opportunities for recombination that helps to

324 break down associations between alleles. Large population sizes, which are not uncommon in $B$.

325 stacei, might also reduce linkage disequilibrium. For instance, the near worldwide-distributed

326 Arabidopsis thaliana is predominantly a selfing annual species but exhibits a rapid decay in

327 linkage drag in several populations (Nordborg et al. 2005).

328

329 Origin of island populations

330 Many plant phylogeographic studies have concluded that genetic diversity erodes across

331 colonization steps, but islands usually exhibit high frequencies of endemism in comparison with

332 large continental areas as a consequence of isolation and habitat diversity (Kim et al. 1996;

333 Sanmartín et al. 2008; Vitales et al. 2014; see review in Caujapé-Castells 2011). In our study, the

334 genetic structure retrieved by the Bayesian analyses of STRUCTURE or BAPS, or by the results

335 retrieved from the PCoA and the $\mathrm{NJ}$ tree suggests a scenario of colonization from the mainland

336 Iberian Peninsula into the islands. Individuals collected in Minorca clustered with SE mainland

337 Iberian populations, whereas individuals from the Canary Islands and most of the Majorcan

338 populations were clustered with S mainland populations (with the exception of BONA which is

339 more related to the SE mainland populations). The large number of alleles (89\%) shared between

340 the individuals collected in the Canary Islands and the ones collected in S Spain could support

341 the hypothesis of colonization from the mainland Iberian Peninsula. A recent colonization 
342 scenario from a mainland Iberian source fits well the plausible origin of the oceanic Canary

343 island populations, which show low levels of genetic diversity and multilocus genetic profiles

344 that are a subset of those found in S Spain (Table 1, Fig. 2). Additionally, Canarian populations

345 of $B$. stacei have shown to be phenotypically close to S Spain populations (Lopez-Alvarez,

346 Catalán, unpublished data). However, islands could have also been colonized by North African

347 coastal populations of $B$. stacei since ecological niche models predict the existence of conditions

348 suitable for the existence of this species in that area (López-Alvarez et al. 2015).

349 Single vs. multiple colonization scenarios from mainland Iberian sources have been

350 proposed to explain the origins of the Macaronesian plant populations (cf. Diaz-Pérez et al.

351 2012); however, most of them gave rise to new species (Kim et al. 1996; Francisco-Ortega et al.

352 1996; 1997; Caujapé-Castells 2011). Even if B. stacei grows preferentially in relatively stable

353 shady coastal and lowland places along its distribution area (Catalan et al. 2016a), seeds of this

354 annual species could be also occasionally dispersed through long distances, as inferred from

355 genetic studies (López-Alvarez et al. 2012). The fact that all the studied individuals of the

356 Canarian GOM and LAN populations are morphologically similar to those of the remaining

357 Mediterranean populations (Catalán et al. 2016a) indicates that they belong to the same species,

358 suggesting that the introduction of the plant in the Canary isles was probably a very recent one.

359 Contrastingly, the Balearic populations of B. stacei show similar, or even higher genetic

360 diversity values in the case of the Majorcan populations (e.g., BONA, Majorca; Table 1), than

361 the mainland Iberian populations. This scenario could be explained by old colonization events

362 from the mainland followed by insular isolation, which might have favored the appearance and

363 accumulation of new allelic variants and genotypes along time (Fig. 2). Also, admixture after

364 multiple colonization's could have contributed to this scenario, which has been reported to have 
365 occurred in other postglacial recolonizations in Europe (e. g., Lexer et al 2010; Krojerová-

366 Prokesová et al. 2005). The palaeogeographic configuration of the continental Balearic Islands

367 could have facilitated the migration of coastal SE Spain and S Spain B. stacei populations into

368 Minorca and Majorca, and the repeated colonization (and admixture) of the later island from

369 multiple continental sources (Fig. 4). The southern Iberian region together with its eastern

370 Iberian range, the Balearic isles and Provence formed a continuous geological region that split

371 into several microplates during the Oligocene (Cohen 1980). In the late Oligocene (30-28 Ma)

372 the Balearic microplate separated from the eastern proto-Iberian peninsula (Cohen 1980;

373 Rosenbaum et al. 2002) but during the Messinian drought and salinity crisis of the Mediterranean

374 in the late Miocene (c. 6-5 Ma), the Balearic islands formed a single land mass (Gautier et al.

375 1994) and several land bridges re-established the connection with the eastern Iberian Peninsula

376 (Lalueza-Fox et al. 2005). Even after the opening of the Gibraltar strait and the refilling of the

377 Mediterranean basin (c. $5 \mathrm{Ma}$ ), several land bridges were again created during Middle-Upper

378 Pleistocene that connected the Balearic Gymnesian isles between themselves and between those

379 islands and the mainland eastern Iberian Peninsula (c. 0. 40 Ma; Cuerda 1975), favoring the

380 colonization of the islands from mainland plant populations stocks (Garnatje et al. 2013).

381

382 Is there a role for ecogeographical isolation in Brachypodium?

383 High values of genetic differentiation and a signature of strong genetic structure were found in $B$.

384 stacei. Though genetic differentiation values obtained for other selfing but more outcrossing

385 species of Brachypodium are relatively high (e. g., B. sylvaticum: $F_{\mathrm{ST}} 0.480 \pm 0.28$ in native

386 Eurasian populations, and $0.446 \pm 0.26$ in invasive western North American populations;

387 Rosenthal et al. 2008), the high values of genetic differentiation found in B. stacei are puzzling. 
388 Lower genetic differentiation values than the ones found here usually correspond to different

389 grass species (e. g., Festuca, Diaz-Perez et al. 2008). However, all B. stacei individuals

390 examined in this study are morphologically similar and correspond to what is considered to be

391 the same species (Catalan et al. 2016a). Population turnover is expected to increase genetic

392 differentiation among populations if colonizers are dispersed from different sources (Pannell \&

393 Charlesworth 2000). That might only be true for B. stacei if wind or other vectors are dispersing

394 seeds across populations, as hypothesized for the also annual and autogamous $B$. distachyon

395 (Vogel et al. 2009; Mur et al. 2011). That would probably erase the patterns of genetic structure

396 that we have found in STRUCTURE, BAPS, the NJ tree and the PCoA analyses (Figs. 3-5),

397 though the high rates of selfing observed could explain the high levels of genetic differentiation

398 and strong population structure of B. stacei, like reported in other primarily selfing plants

399 (Nybom 2004).

400 Because plants are sessile they experience generations of selection that result in adaptive 401 genetic differentiation to local environmental conditions if there is a strong pressure (Kremer et 402 al. 2014). Although we have no empirical information for B. stacei, the distribution of the close 403 relatives, $B$. distachyon and its allopolyploid derivative $B$. hybridum, indicates that they are 404 405 geographically structured in mesic to arid environments, with $B$. distachyon occurring predominantly in more mesic sites and B. hybridum in more aridic sites (Manzaneda et al. 2012). Brachypodium hybridum is also more efficient in its water usage being significantly more

407 tolerant to drought than B. distachyon and behaving as a drought-escapist (Manzaneda et al. 408 2015). Also, environmental niche model analyses indicate a preference of $B$. stacei for warm and arid Mediterranean places (Lopez-Alvarez et al. 2015), though its habitat preferences are for

410 shady places, probably as a protection from direct insulation in the aridic environment (Catalán 
411 et al. 2016a). Therefore, all together, results suggest an important role for ecogeographical

412 differentiation in these lineages of Brachypodium (Manzaneda et al. 2012, 2015; Lopez-Alvarez

413 et al. 2015; Catalán et al. 2016a,b). More detailed ecological studies are necessary to understand

414 the potential ecological tolerance of $B$. stacei to the arid conditions.

415

416 Perspectives towards new genomics initiatives in B. stacei

417 The ongoing de-novo genome sequencing of B. stacei led by the Joint Genome Institute and the

418 International Brachypodium Consortium

419 (http://brachypodium.pw.usda.gov/files/resequencing_description_110822.pdf) will provide

420 significant insights into the mechanisms of polyploid hybrid speciation within the complex $B$.

421 distachyon - B. stacei - B. hybridum, also allowing comparative studies of genomics and

422 development of functional traits in other crop plants. Biological features, such as a selfing

423 system, a diploid genome and having amenable growing conditions are all advantages for the

424 development of a model system and for genomic resources. All seem to be present in B. stacei.

425 Previous studies showed that the species is diploid (Catalán et al. 2012) and can easily grow even

426 in laboratory conditions, germinating in less than one week like we have seen in our own

427 laboratory (Catalán, unpublished data).

428 The results from the present study support the existence of a highly selfing system, which

429 from a practical perspective is an advantage in a model species since it simplifies the process of

430 obtaining pure lines under laboratory conditions (Gordon et al. 2014). But plant breeding

431 requires the presence of genetic variability in order to increase the frequencies of favorable

432 alleles and genetic combinations. Populations from SE Spain are genetically different from the

433 ones in S Spain and further differentiation might occur in the islands especially in Majorca and 
434 Minorca, where several unique alleles were found. Future studies need to test if population

435 differentiation reflects local adaptation to different environments. Nonetheless, researchers of

436 GWA studies need to be careful to avoid reporting false positive signals (i.e., identifying loci that

437 are not responsible for the variation in the trait), which can be caused by population structure

438 (Platt et al. 2010; Brachi et al. 2011). In this sense, several efforts have been raised to address

439 this problem statistically (Pritchard et al. 2000b; Price et al. 2006; Yu et al. 2006) and recent

440 GWAS can detect loci that are involved in the natural variation of traits even in highly structure

441 plants like Arabidopsis (Nordborg et al. 2005).

442 Thus, to help future genomic initiatives involving B. stacei we recommend the following

443 guidelines: (1) a collection of different accessions reflecting different ecological pressures should

444 be generated in order to recover the full genomic diversity of B. stacei; (2) the creation of a gene

445 bank collection of these materials constitutes a practical and useful reservoir of genetic variation

446 to avoid uniform cultivars and genetic erosion; (3) collections should be accessible to facilitate

447 the interchange of material useful for breeding and other studies. Finally, there is a lack of

448 information for other areas of the Mediterranean, especially the Eastern Mediterranean - SW

449 Asian area, where B. stacei has been also found (López-Alvarez et al. 2012, 2015; Catalán et al.

450 2016a). A comprehensive study including populations from other Mediterranean areas is

451 compulsory to fully discover the phylogeographic patterns and genetic diversity of B. stacei.

452

453 Acknowledgments

454 We thank the Spanish Centro de Recursos Fitogenéticos (CRF-INIA), Consuelo Soler and

455 Antonio Manzaneda for providing us some B. stacei seeds, Maria Luisa López-Herranz and 
456 Diana López-Alvarez for laboratory and greenhouse assistance, and William Scott for linguistic 457 assistance.

458

\section{References}

460 Brachi B, Morris GP, Borevitz JO. 2011. Genome-wide association studies in plants: the missing 461 heritability is in the field. Genome Biology 2011 12:232.

462 Catalán P, Müller J, Hasterok R, Jenkins G, Mur LAJ, Langdon T, Betekhtin A, Siwinska D, 463 Pimentel M, López-Alvarez D. 2012.Evolution and taxonomic split of the model grass 464 Brachypodium distachyon (L.) P. Beauv. Annals of Botany 109:385-405.

465 Catalán P, López-Alvarez D, Bellosta C, Villar L. 2016a. Updated taxonomic descriptions, 466 iconography, and habitat preferences of Brachypodium distachyon, B. stacei and B. hybridum 467 (Poaceae). Anales Jardin Botánico Madrid 73(1): e028.

468 Catalán P, López-Alvarez D, Díaz-Pérez A, Sancho R, López-Herranz ML. 2016b. Phylogeny 469 and evolution of the genus Brachypodium. In Vogel J (ed.). Genetics and genomics of 470 Brachypodium. pp. 9-38. Series Plant Genetics and Genomics: Crops Models. Springer. New 471 York.

472 Caujapé-Castells J. 2011. Jesters, red queens, boomerangs and surfers: a molecular outlook on 473 the diversity of the Canarian endemic flora. In: Bramwell D, Caujapé-Castells J, editors. The 474 biology of islands floras. Cambridge: Cambridge University Press. pp. 284-234.

475 Charlesworth B, Charlesworth D. 2000. The degeneration of Y chromosomes. Philos. Trans. R. 476 Soc. Lond. B. Biol. Sci. 355(1403): 1563-1572.

477 Charlesworth D, Willis JH. 2009. The genetics of inbreeding depression. Nat. Rev. Genet. 10: $478 \quad 783-796$. 
479 Chybicki IJ, Burczyk J. 2009. Simultaneous estimation of null alleles and inbreeding 480 coefficients. Journal of Heredity 100: 106-113.

481 Chybicki IJ, Oleksa A, Burczyk J. 2011. Increased inbreeding and strong kinship structure in 482 Taxus baccata estimated from both AFLP and SSR data. Heredity 107:589-600.

483 Cohen C.R. 1980. Plate-tectonic model for the Oligo-Miocene evolution of the Western 484 Mediterranean. Tectonophysics 68: 283-311.

485 Corander J, Marttinen P, Mantyniemi S. 2006. Bayesian identification of stock mixtures from 486 molecular marker data. Fishery Bulletin 104: 550-558.

487 Cuerda J. 1975. Los tiempos cuaternarios en Baleares. Instituto de Estúdios Baleáricos: Palma de 488 Mallorca.

489 Díaz-Pérez A, Sequeira MM, Santos-Guerra A Catalán P. 2008. Multiple colonizations, in-situ 490 speciation, and volcanism- associated stepping-stone dispersals shaped the phylogeography of 491 the Macaronesian red fescues (Festuca L. Gramineae). Systematic Biology 57: 732-749. 492 Díaz-Pérez AJ, Sequeira M, Santos-Guerra A, Catalán P 2012. Divergence and biogeography of the 493 recently evolved Macaronesian red Festuca (Gramineae) species inferred from coalescence-based 494 analyses. Molecular Ecology 21(7): 1702-1726.

495 Draper J, Mur LAJ, Jenkins G, Ghosh-Biswas GC, Bablak P, Hasterok R, Routledge APM. 2001. 496 Brachypodium distachyon. A new model system for functional genomics in grasses. Plant 497 Physiology 127, 1539-1555.

498 Earl DA, vonHoldt BM. 2012. STRUCTURE HARVESTER: a website and program for 499 visualizing STRUCTURE output and implementing the Evanno method. Conservation Genetics 500 Resources 4: 359-361 doi: 10.1007/s12686-011-9548-7.

501 Evanno G, Regnaut S, Goudet J. 2005. Detecting the number of clusters of individuals using the 502 software STRUCTURE: A simulation study. Molecular Ecology 14: 2611-2620. 
503 Excoffier L, Laval G, Schneider S. 2005. Arlequin (version 3.0): an integrated software package

504 for population genetics data analysis. Evolutionary Bioinformatics Online 1: 47-50.

505 Francisco-Ortega J, Jansen RK, Santos-Guerra A. 1996. Chloroplast DNA evidence of

506 colonization, adaptive radiation, and hybridization in the evolution of the Macaronesian flora.

507 Proceedings of the National Academy of Sciences of the USA 93: 4085-4090.

508 Francisco-Ortega J, Santos-Guerra A, Hines A, Jansen RK. 1997. Molecular evidence for a

509 Mediterranean origin of the Macaronesian endemic genus Argyranthemum (Asteraceae).

510 American Journal of Botany 84: 1595-1613.

511 Garnatje T, Pérez-Collazos E, Pellicer J, Catalán P. 2013. Balearic insular isolation and large

512 continental spread framed the phylogeography of the western Mediterranean Cheirolophus

513 intybaceus (Asteraceae). Plant Biology 15: 166-175.

514 Gautier F, Caluzon G, Suk JP, Violanti D. 1994. Age et durée de la crise de salinité Messinienne.

515 Comptes Rendus de l'Académie des Sciences de Paris, 318, 1103-1109.

516 Giraldo P, Rodriguez-Quijano M, Vazquez JF, Carillo JM, Benavente E. 2012. Validation of

517 microsatellite markers for cytotype descrimination in the model grass Brachypodium. Genome

$518 \quad 55: 1-5$.

519 Goldberg EE, Kohn JR, Lande R, Robertson KA, Smith SA, Igic B. 2010. Species Selection

520 Maintains Self-Incompatibility. Science 330: 493-95.

521 Gordon SP, Priest H, Des Marais DL, Schackwitz W, Figueroa M, Martin J, Bragg JN, Tyler L,

522 Lee C.-R, Bryant D, Wang W, Messing J, Manzaneda AJ, Barry K, Garvin DF, Budak H, Tuna

523 M, Mitchell-Olds T, Pfender WF, Juenger TE, Mockler TC, Vogel JP.2014. Genome diversity in

524 Brachypodium distachyon: deep sequencing of highly diverse inbred lines. Plant J. 79:361-74. 
525 Goudet J. 2001. FSTAT, a program to estimate and test gene diversities and fixation indices

526 (version 2.9.3). Available from http://www.unil.ch/izea/softwares/fstat.html. Updated from

527 Goudet (1995).

528 Hammami R, Jouve N, Cuadrado A, Soler C, Gonzalez JM. 2011. Prolamin storage proteins and 529 alloploidy in wild populations of the small grass Brachypodium distachyon (L.) P. Beauv. Plant 530 Systematics and Evolution 297: 99-111.

531 Igic B, Busch JW. 2013. Is self-fertilization an evolutionary dead end? New Phytologist 198: $532 \quad 386-397$.

533 International Brachypodium Initiative (IBI). 2010. Genome sequencing and analysis of the model 534 grass Brachypodium distachyon. Nature 463: 763-768.

535 International Rice Genome Sequencing Project. 2005. The map-based sequence of the rice 536 genome. Nature 436: 793-800.

537 Jaaska V. 2014. Isozyme variation and differentiation of morphologically cryptic species in the 538 Brachypodium distachyon complex. Biochemical Systematics and Ecology 56: 185-190.

539 Jakobsson M, Rosenberg NA. 2007. CLUMPP: a cluster matching and permutation program for 540 dealing with label switching and multimodality in analysis of population structure.

541 Bioinformatics 23:1801-1806

542 Kellogg EA. 2001. Evolutionary history of the grasses. Plant Physiology 125: 1198-1205.

543 Kim S, Crawford D, Francisco-Ortega J, Santos-Guerra A. 1996. A common origin for woody

544 Sonchus and five related genera in the Macaronesian islands: molecular evidence for extensive

545 radiation. Proceedings of the National Academy of Sciences 93: 7743-7748.

546 Kremer A, Potts BM, Delzon S. 2014. Genetic divergence in forest trees: understanding the 547 consequences of climate change. Functional Ecology 28: 22-36. 
548 Langella O. POPULATIONS 1·2: population genetic software, individuals or population

549 distance, phylogenetic trees. 2000. http://bioinformatics.org/ tryphon/populations/.

550 Lalueza-Fox C, Castresana J, Sampietro L, Marquès-Bonet T, Alcover JA,

551 Bertranpetit J. 2005. Molecular dating of caprines using ancient DNA sequences of Myotragus

552 balearicus, an extinct endemic Balearic mammal. BMC Evolutionary Biology 5: 70.

553 Lexer C, Joseph JA, van Loo M, Barbará T, Heinze B, Bartha D, Castiglione S, Fay MF, Buerkle

554 AC. 2010. Genomic admixture analysis in European Populus spp. reveals unexpected patterns of

555 reproductive isolation and mating. Genetics 186: 699-712.Lin J-Z, Brown AHD, Clegg MT.

556 2001. Heterogeneous geographic patterns of nucleotide sequence diversity between two alcohol

557 dehydrogenase genes in wild barley (Hordeum vulgare subspecies spontaneum) Proceedings of

558 the National Academy of Sciences 98: 531-536.

559 López-Alvarez D, López-Herranz ML, Betekhtin A, Catalán P. 2012. A DNA Barcoding method

560 to discriminate between the model Plant Brachypodium distachyon and its close relatives $B$.

561 stacei and B. hybridum (Poaceae). PLoS ONE 7(12): e51058. doi:10.1371/journal.pone.0051058.

562 López-Alvarez D, Manzaneda A J, Rey PJ, Giraldo P, Benavente E, Allainguillaume J, Mur

563 LAJ, Caicedo AL, Hazen SP, Breiman A, Ezrati S, Catalán P. 2015. Environmental niche

564 variation and evolutionary diversification of the Brachypodium distachyon grass complex species

565 in their native circum-Mediterranean range. American Journal of Botany 102: 1-16.

566 Lynch M, Conery J, Burger R. 1995. Mutation accumulation and the extinction of small

567 populations. The American Naturalist 146: 489-518.

568 Mantel N. 1967. The detection of disease clustering and a generalized regression approach.

569 Cancer Research 27: 209-220. 
570 Manzaneda AJ, Rey PJ, Bastida JM, Weiss-Lehman C, Raskin E, Mitchell-Olds T. 2012.

571 Environmental aridity is associated with cytotype segregation and polyploidy occurrence in

572 Brachypodium distachyon (Poaceae). New Phytologist 193: 797-805.

573 Manzaneda AJ, Rey PJ, Anderson JT, Raskin E, Weiss-Lehman C, Mitchell-Olds T. 2015.

574 Natural variation, differentiation, and genetic trade-offs of ecophysiological traits in response to

575 water limitation in Brachypodium distachyon and its descendent allotetraploid B. hybridum

576 (Poaceae). Evolution 69: 2689-2704.

577 Marques I, Draper D, Iriondo JM. 2014. Costs and benefits of the mixed-mating system of 578 Narcissus serotinus (Amaryllidaceae) in the conservation of small fragmented populations.

579 Botany 92(2): 113-122.

580 Morrell PL, Toleno DM, Lundy KE, Clegg MT. 2005. Low levels of linkage disequilibrium in 581 wild barley (Hordeum vulgare ssp. spontaneum) despite high rates of self-fertilization.

582 Proceedings of the National Academy of Sciences 102(7): 2442-2447.

583 Mur LAJ, Allainguillaume J, Catalán P, Hasterok R, Jenkins G, Lesniewska K, Thomas I, Vogel

584 J. 2011. Exploiting the Brachypodium Tool Box in cereal and grass research. New Phytologist

585 191: 334-347.

586 Nei M, Chesser RK. 1983. Estimation of fixation indices and gene diversities. Ann Hum

587 Genet 47: 253-259.

588 Nordborg M, Hu TT, Ishino Y, Jhaveri J, Toomajian C, Zheng H, Bakker E, Calabrese P,

589 Gladstone J, Goyal R, Jakobsson M, Kim S, Morozov Y, Padhukasahasram B, Plagnol V, 590 Rosenberg NA, Shah C, Wall JD, Wang J, Zhao K, Kalbfleisch T, Schulz V, Kreitman M,

591 Bergelson J. 2005. The pattern of polymorphism in Arabidopsis thaliana. PLoS Biol 3(7): e196. 
592 Nybom H. 2004. Comparison of different nuclear DNA markers for estimating intraspecific 593 genetic diversity in plants. Molecular Ecology 13: 1143-1155.

594 Pannell JR, Charlesworth B. 2000. Effects of metapopulation processes on measures of genetic 595 diversity. Philosophical Transactions of the Royal Society of London Series B 355: 1851-1864.

596 Paterson AH, Bowers JE, Bruggmann R, Dubchak I, Grimwood J, Gundlach H, Haberer G, 597 Hellsten U, Mitros T, Poliakov A, Schmutz J, Spannagl M, Tang H, Wang X, Wicker T, Bharti 598 AK, Chapman J, Feltus FA, Gowik U, Grigoriev IV, Lyons E, Maher C, Martis M, Narechania 599 A, Otillar RP, Penning BW, Salamov AA, Wang Y, Zhang L, Carpita N, Freeling M, Gingle AR, 600 Hash CT, Keller B, Klein P, Kresovich S, McCann MC, Ming R, Peterson DG, Mehboob-ur601 Rahman, Ware D, Westhoff P, Mayer KFX, Messing J, Rokhsar DS.

602 2009. The Sorghum bicolor genome and the diversification of grasses. Nature 457:551-556.

603 Krojerová-Prokesová J, Baranceková M, Koubek P. 2015. Admixture of eastern and 604 western European red deer lineages as a result of postglacial recolonization of the Czech 605 Republic (Central Europe). Journal of Heredity 106: 375-385.

606 Platt A, Vilhjálmsson BJ, Nordborg M. Conditions under which genome-wide association 607 studies will be positively misleading. Genetics 186: 1045-1052.

608 Peakall R,Smouse PE. 2006. GENALEX 6: genetic analysis in Excel. Population genetic 609 software for teaching and research. Molecular Ecology Notes 6:288-295.

610 Price AL, Patterson NJ, Plenge RM, Weinblatt ME, Shadick NA, Reich D. 2006. Principal 611 components analysis corrects for stratification in genome-wide association studies. Nature 612 Genetics 38: 904-909.

613 Pritchard JK, Stephens M, Donnelly, P. 2000a. Inference of population structure using 614 multilocus genotype data. Genetics 155: 945-959. 
615 Pritchard JK, Stephens M, Rosenberg NA, Donnelly P. 2000b. Association mapping in 616 structured populations. American Journal of Human Genetics 67: 170-181.

617 Raymond M, Rousset F. 1995. GENEPOP Version 1.2: population genetics software for exact 618 tests and ecumenicism. Journal of Heredity 86: 248-249.

619 Rice WR. 1989. Analyzing tables of statistical tests. Evolution 43: 223-225.

620 Ritland K. 1990. Inferences about inbreeding depression based on changes of the inbreeding 621 coefficient. Evolution 44: 1230-1241.

622 Robertson IH. 1981. "Chromosome numbers in Brachypodium Beauv. (Gramineae)." Genetica $623 \quad 56(1): 55-60$.

624 Rosenbaum G, Lister GS, Duboz C. 2002. Reconstruction of the tectonic evolution in the 625 western Mediterranean since the Oligocene. In: Rosenbaum G., Lister G.S. (Eds.) Reconstruction 626 of the evolution of the Alpine-Himalayan Orogeny. Journal of the Virtual Explorer 8: 107-130.

627 Rosenthal DM, Ramakrishnan AP, Cruzan MB. 2008. Evidence for multiple sources of invasion 628 and intraspecific hybridization in Brachypodium sylvaticum (Hudson) Beauv. in North America. 629 Molecular Ecology 17:4657-4669.

630 Sanmartín I, van der Mark P, Ronquist F. 2008. Inferring dispersal: a Bayesian approach to 631 phylogeny-based island biogeography, with special reference to the Canary Islands. Journal of 632 Biogeography 35: 428-449.

633 Soreng RJ, Peterson PM, Romaschenko K, Davidse G, Zuloaga F.O., Judziewicz E.J., Filgueiras 634 T. S., Davis J.I., Morrone O. 2015. A worldwide phylogenetic classification of the Poaceae 635 (Gramineae). Journal of Systematics and Evolution 53: 117-137. 
636 Steinwand MA, Young HA, Bragg JN, Tobias CM, Vogel JP. 2013. Brachypodium sylvaticum, a

637 Model for perennial grasses: transformation and inbred line development. PLoS ONE 8(9):

638 e75180. doi:10.1371/journal.pone.0075180.

639 Tyler L, Lee SJ, Young N, Delulio GA, Benavente E, Reagon M, Sysopha J, Baldini RM, Troia

640 A, Hazen SP, Caicedo AL. 2016. Population structure in the model grass Brachypodium

641 distachyon is highly correlated with flowering differences across broad geographic areas. The

642 Plant Genome. doi: 10.3835/plantgenome2015.08.0074.

643 van Oosterhout C, Hutchinson WF, Wills DPM, Shipley P. 2004. MICRO-CHECKER: software

644 for identifying and correcting genotyping errors in microsatellite data. Molecular Ecology

645 Resources 4: 535-538.

646 Vitales D, Garnatje T, Pellicer J, Vallès J, Santos-Guerra A, Sanmartín I. 2014. The explosive 647 radiation of Cheirolophus (Asteraceae, Cardueae) in Macaronesia. BMC Evol Biol 14: 118. doi:

648 10.1186/1471-2148-14-118.

649 Vogel JP, Tuna M, Budak H, Huo N, Gu Y-Q, Steinwand MA. 2009. Development of SSR

650 markers and analysis of diversity in Turkish populations of Brachypodium distachyon. BMC

651 Plant Biol. 9(1): 88.

652 Yu J, Pressoir G, Briggs W, Vroh Bi I, Yamasaki M, Doebley JF, McMullen MD, Gaut BS, Nielsen DM,

653 Holland JB, Kresovich S, Edward S Buckler ES. 2006. A unified mixed-model method for association

654 mapping that accounts for multiple levels of relatedness. Nature Genetics 38: 203-208. 
Table 1. Sampled populations of Brachypodium stacei sorted by geographical area. The location, population code, number of plants genotyped $(N)$, mean observed heterozygosity $\left(H_{o}\right)$ and expected heterozygosity $\left(H_{e}\right)$, mean number of alleles $\left(N_{A}\right)$, allelic richness $\left(A_{R}\right)$, inbreeding coefficient $\left(\mathrm{F}_{\mathrm{IS}}\right)$, selfing rate $(s)$, and number of exclusive genotypes $(\%$. between parenthesis) are shown. Asterisks indicate $\mathrm{F}_{\mathrm{IS}}$ values deviating from $\operatorname{HWE}(P>0.05)$.

\begin{tabular}{|c|c|c|c|c|c|c|c|c|c|c|c|}
\hline Locality & Code & $\mathbf{N}$ & Latitude (N) & Longitude (W) & $\mathbf{H}_{\mathbf{0}}$ & $\mathbf{H}_{\mathrm{e}}$ & $\mathbf{N}_{\mathbf{A}}$ & $\mathbf{A}_{\mathrm{R}}$ & $\mathbf{F}_{\text {IS }}$ & $\mathbf{s}$ & $\begin{array}{l}\text { Exclusive } \\
\text { genotypes }\end{array}$ \\
\hline \multicolumn{12}{|l|}{ Mainland (Iberian Peninsula) } \\
\hline S Spain: Granada, Moclin & GRA & 10 & $37^{\circ} 19^{\prime} 59^{\prime \prime} \mathrm{N}$ & $3^{\circ} 46^{\prime} 59^{\prime \prime} \mathrm{W}$ & 0.240 & 0.155 & 12 & 1.126 & 0.667 & 0.800 & $3(30 \%)$ \\
\hline S Spain: Almeria, Cabo de Gata & ALM & 10 & $36^{\circ} 44^{\prime} 2^{\prime \prime} \mathrm{N}$ & $2^{\circ} 8^{\prime} 35^{\prime \prime} \mathrm{W}$ & 0.170 & 0.102 & 11 & 1.050 & 0.0001 & 0.0001 & $3(30 \%)$ \\
\hline S Spain: Jaen: Cazorla, Cortijos Nuevos & JAE1 & 10 & $38^{\circ} 11^{\prime} 31^{\prime \prime} \mathrm{N}$ & $2^{\circ} 48^{\prime} 14^{\prime \prime} \mathrm{W}$ & 0.120 & 0.116 & 12 & 1.176 & $0.723 *$ & 0.839 & $4(40 \%)$ \\
\hline S Spain: Jaen: Quesada, Tiscar & JAE2 & 10 & $37^{\circ} 465^{\prime \prime} \mathrm{N}$ & $3^{\circ} 1{ }^{\prime} 23^{\prime \prime} \mathrm{W}$ & 0.200 & 0.100 & 10 & 1.000 & - & - & $1(10 \%)$ \\
\hline SE Spain: Murcia, Portman & PORT & 10 & $37^{\circ} 34^{\prime} 57^{\prime \prime} \mathrm{N}$ & $0^{\circ} 51^{\prime} 15^{\prime \prime} \mathrm{W}$ & 0.200 & 0.100 & 10 & 1.000 & - & - & $1(10 \%)$ \\
\hline SE Spain: Murcia: Calblanque & $\begin{array}{l}\text { CALB } \\
\mathrm{N}\end{array}$ & 10 & $37^{\circ} 35^{\prime} 59^{\prime \prime} \mathrm{N}$ & $0^{\circ} 45^{\prime} 29^{\prime \prime} \mathrm{W}$ & 0.140 & 0.108 & 14 & 1.246 & $0.526^{*}$ & 0.689 & $4(40 \%)$ \\
\hline SE Spain: Murcia: Cobaticas & $\begin{array}{l}\text { CALB } \\
\text { A }\end{array}$ & 10 & $37^{\circ} 35^{\prime} 59^{\prime \prime} \mathrm{N}$ & $0^{\circ} 45^{\prime} 30^{\prime \prime} \mathrm{W}$ & 0.110 & 0.105 & 15 & 1.339 & $0.617 *$ & 0.763 & $5(50 \%)$ \\
\hline SE Spain: Murcia, Cala Reona & $\begin{array}{l}\text { CALRE } \\
\text { L }\end{array}$ & 10 & $37^{\circ} 36^{\prime} 56^{\prime \prime} \mathrm{N}$ & $0^{\circ} 42^{\prime} 56^{\prime \prime} \mathrm{W}$ & 0.030 & 0.009 & 13 & 1.239 & $0.520 *$ & 0.684 & $5(50 \%)$ \\
\hline SE Spain: Alicante, Cano La Nao & ALI & 5 & $38^{\circ} 45^{\prime} 22^{\prime \prime} \mathrm{N}$ & $0^{\circ} 13^{\prime} 8^{\prime \prime} \mathrm{E}$ & 0.300 & 0.150 & 10 & 1.000 & - & - & $1(20 \%)$ \\
\hline \multicolumn{12}{|l|}{ Balearic (Gymnesic) Islands } \\
\hline Minorca: Es Mercadal, Toro & MEN & 10 & $39^{\circ} 59^{\prime} 6^{\prime \prime} \mathrm{N}$ & $4^{\circ} 6^{\prime} 47^{\prime \prime} \mathrm{E}$ & 0.240 & 0.173 & 13 & 1.203 & $0.386^{*}$ & 0.556 & $3(30 \%)$ \\
\hline Majorca: Sa Dragonera, Gambes & DRAG & 10 & $39^{\circ} 35^{\prime} 13^{\prime \prime} \mathrm{N}$ & $2^{\circ} 19^{\prime} 37^{\prime \prime} \mathrm{E}$ & 0.111 & 0.154 & 16 & 1.428 & $0.916^{*}$ & 0.956 & $5(50 \%)$ \\
\hline Majorca: Arta, Peninsula de Llevant & ARTA & 10 & $39^{\circ} 44^{\prime} 10^{\prime \prime} \mathrm{N}$ & $3^{\circ} 20^{\prime} 6^{\prime \prime} \mathrm{E}$ & 0.210 & 0.128 & 12 & 1.126 & $0.666^{*}$ & 0.799 & $3(30 \%)$ \\
\hline Majorca: Campanet, Coves & $\begin{array}{l}\text { CAMP } \\
\text { A }\end{array}$ & 10 & $39^{\circ} 47^{\prime} 31^{\prime \prime} \mathrm{N}$ & $2^{\circ} 58^{\prime} 12^{\prime \prime} \mathrm{E}$ & 0.130 & 0.138 & 14 & 1.434 & $0.486^{*}$ & 0.654 & $6(60 \%)$ \\
\hline Majorca: Alcudia, Punta Negra & ALCU & 10 & $39^{\circ} 52^{\prime} 48^{\prime \prime} \mathrm{N}$ & $3^{\circ} 10^{\prime} 41^{\prime \prime} \mathrm{E}$ & 0.140 & 0.108 & 14 & 1.200 & 0.0001 & 0.0001 & $2(20 \%)$ \\
\hline Majorca: Felenitx, San Salvador & FELEN & 10 & $39^{\circ} 27^{\prime} 4 " \mathrm{~N}$ & $3^{\circ} 11^{\prime} 17^{\prime \prime} \mathrm{E}$ & 0.130 & 0.109 & 14 & 1.200 & 0.250 & 0.400 & $4(40 \%)$ \\
\hline Majorca: Petra, Bonany & BONA & 10 & $39^{\circ} 35^{\prime} 38^{\prime \prime} \mathrm{N}$ & $3^{\circ} 5^{\prime} 10^{\prime \prime} \mathrm{E}$ & 0.290 & 0.391 & 23 & 1.992 & $0.385^{*}$ & 0.5555 & $9(90 \%)$ \\
\hline Majorca: Banyalbufar, Ses Animes & $\begin{array}{l}\text { BANY } \\
\text { A }\end{array}$ & 6 & $39^{\circ} 41^{\prime} 6^{\prime \prime} \mathrm{N}$ & $2^{\circ} 30^{\prime} 36^{\prime \prime} \mathrm{E}$ & 0.167 & 0.239 & 15 & 1.496 & $0.825^{*}$ & 0.904 & $6(100 \%)$ \\
\hline \multicolumn{12}{|l|}{ Canary Islands } \\
\hline Gomera: Agulo & GOM & 10 & $28^{\circ} 10^{\prime} 59^{\prime \prime} \mathrm{N}$ & $17^{\circ} 10^{\prime} 59^{\prime \prime} \mathrm{W}$ & 0.150 & 0.118 & 11 & 1.076 & 0.891 & 0.942 & $2(20 \%)$ \\
\hline Lanzarote: Teguise & LAN & 10 & $29^{\circ} 4^{\prime} 1 " \mathrm{~N}$ & $13^{\circ} 31^{\prime} 1 " \mathrm{~W}$ & 0.230 & 0.136 & 11 & 1.096 & $1.000^{*}$ & 1 & $2(20 \%)$ \\
\hline
\end{tabular}


659

660

661

662

663

664

665

666

667

668

669

670 
Table 2. Results of the Hardy Weinberg Exact Tests retrieved by GENEPOP for 19 populations of Brachypodium stacei. P-value (0.05) associated with the null hypothesis of random union of gametes (or '-' if no data were available, or only one allele was present) estimated with a Markov chain algorithm and the standard error (S.E.) of this estimate.

\begin{tabular}{lcc}
\hline Population & $\boldsymbol{P}$-value & SE \\
\hline GRA & 0.0519 & 0.0011 \\
ALM & - & \\
JAE1 & 0.0259 & 0.0007 \\
JAE2 & - & \\
PORT & - & \\
CALBN & 0.0077 & 0.0009 \\
CALBA & 0.0007 & 0.0001 \\
CALREL & 0.0249 & 0.0006 \\
ALI & - & \\
MEN & 0.1016 & 0.0015 \\
DRAG & 0 & 0 \\
ARTA & 0.053 & 0.0012 \\
CAMPA & 0.0361 & 0.0014 \\
ALCU & - & \\
FELEN & 0.0508 & 0.0028 \\
BONA & 0 & 0 \\
BANYA & 0 & 0 \\
GOM & 0.0515 & 0.0012 \\
LAN & 0.0096 & 0.0005 \\
\hline
\end{tabular}




\begin{tabular}{llllll}
\hline Locus & Repeat motif & $\mathbf{N}_{\mathbf{a}}$ & $\mathbf{H}_{\mathbf{e}}$ & $\mathbf{H}_{\mathbf{o}}$ & $\mathbf{F}_{\mathbf{I S}}$ \\
\hline$A L B 006$ & $(\mathrm{GT}) 15$ & 2 & 0.016 & 0.016 & 0.003 \\
$A L B 022$ & $(\mathrm{CT}) 11$ & 2 & 0.035 & 0.005 & 0.848 \\
$A L B 040$ & $(\mathrm{CTT}) 8$ & 4 & 0.129 & 0.047 & 0.632 \\
$A L B 050$ & $(\mathrm{GT}) 15$ & 4 & 0.122 & 0.032 & 0.717 \\
$A L B 086$ & $(\mathrm{AAG}) 7$ & 6 & 0.119 & 0.058 & 0.486 \\
$A L B 087$ & $(\mathrm{AGC}) 7$ & 6 & 0.145 & 0.032 & 0.758 \\
$A L B 139$ & $(\mathrm{AGA}) 7$ & 1 & 0.000 & 0.000 & 0 \\
$A L B 165$ & $(\mathrm{ATA}) 12$ & 4 & 0.066 & 0.049 & 0.298 \\
$A L B 181$ & $(\mathrm{AC}) 9$ & 5 & 0.049 & 0.037 & 0.253 \\
$A L B 311$ & (GA)6 & 3 & 0.025 & 0.026 & -0.069 \\
\hline
\end{tabular}

Table 3. Characteristics and genetic diversity statistics of the nuclear microsatellite markers used in the genetic study of Brachypodium stacei. For each locus, the total number of alleles $(\mathrm{Na})$, mean expected heterozygosity (He), mean observed heterozygosity $(\mathrm{Ho})$, and the fixation index $\left(\mathrm{F}_{\mathrm{IS}}\right)$ obtained from the 181 studied individuals are shown.
680

4 86 87 88 89 a 85 


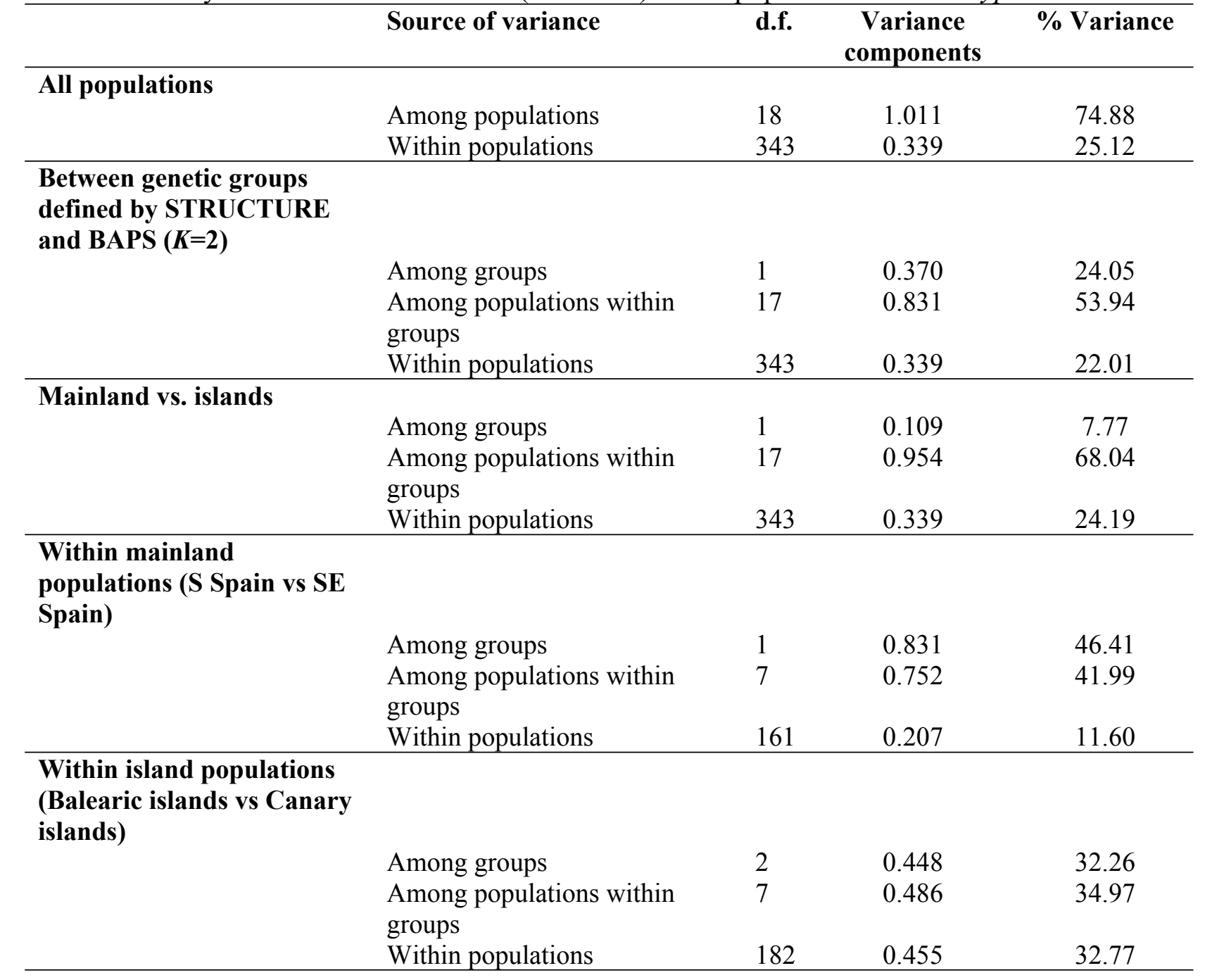

691 
Figure 1 (on next page)

Location of the study area of Brachypodium stacei

Collection localities of Brachypodium stacei populations in mainland Iberian Peninsula, the continental Balearic (Gymnesic) Islands (Minorca and Majorca) and the oceanic Canary Islands. Pie-charts indicate the proportion of ancestry assigned to individuals of each population by Bayesian clustering analysis using STRUCTURE. 


\section{PeerJ}

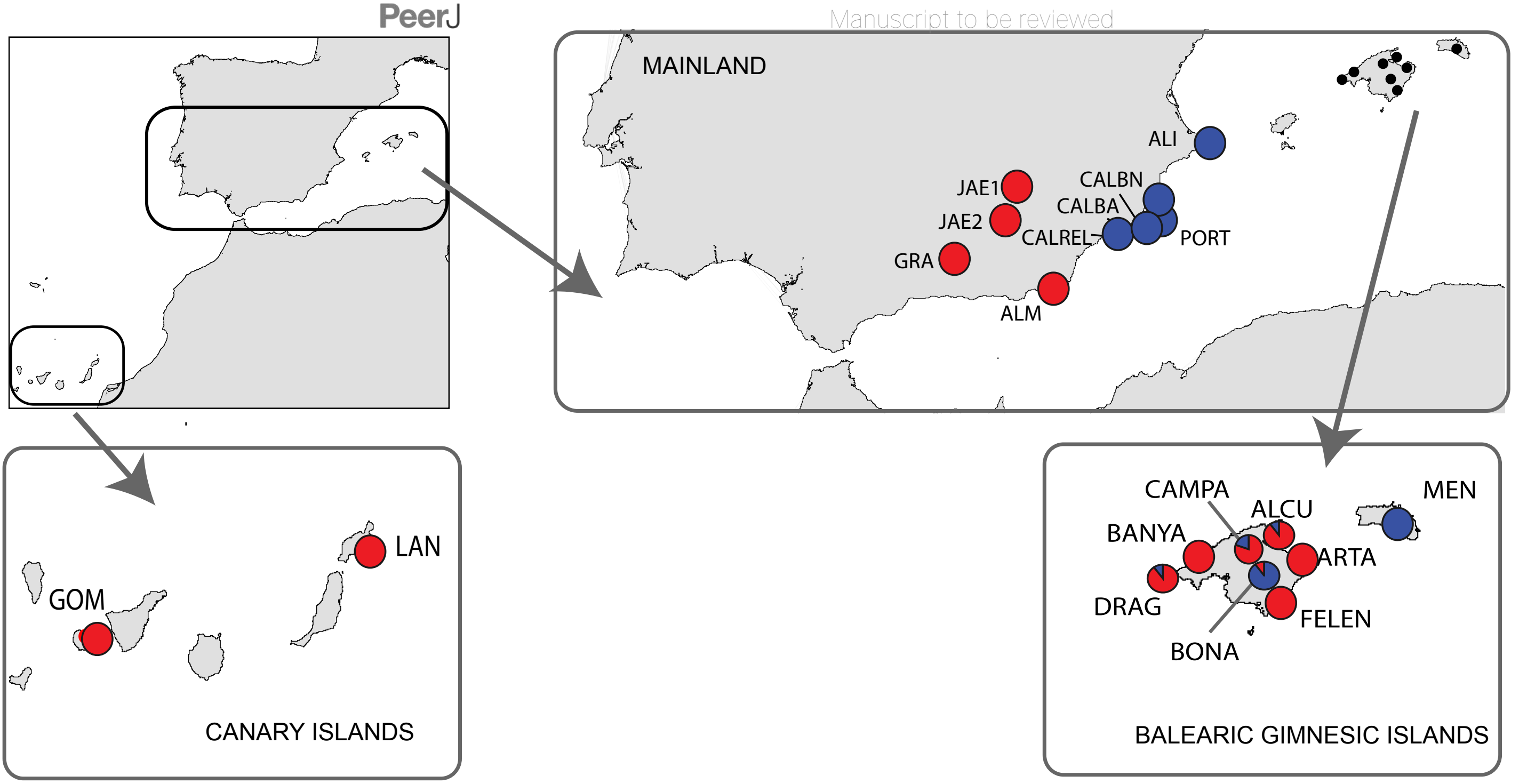


Figure 2 (on next page)

Distribution of Brachypodium stacei alleles.

Frequency of the alleles found in Brachypodium stacei across the geographical area sampled:

mainland Iberian Peninsula (SE Spain and S Spain) and the islands of Minorca, Majorca and the Canary Islands. Colors of areas are indicated in the chart. 


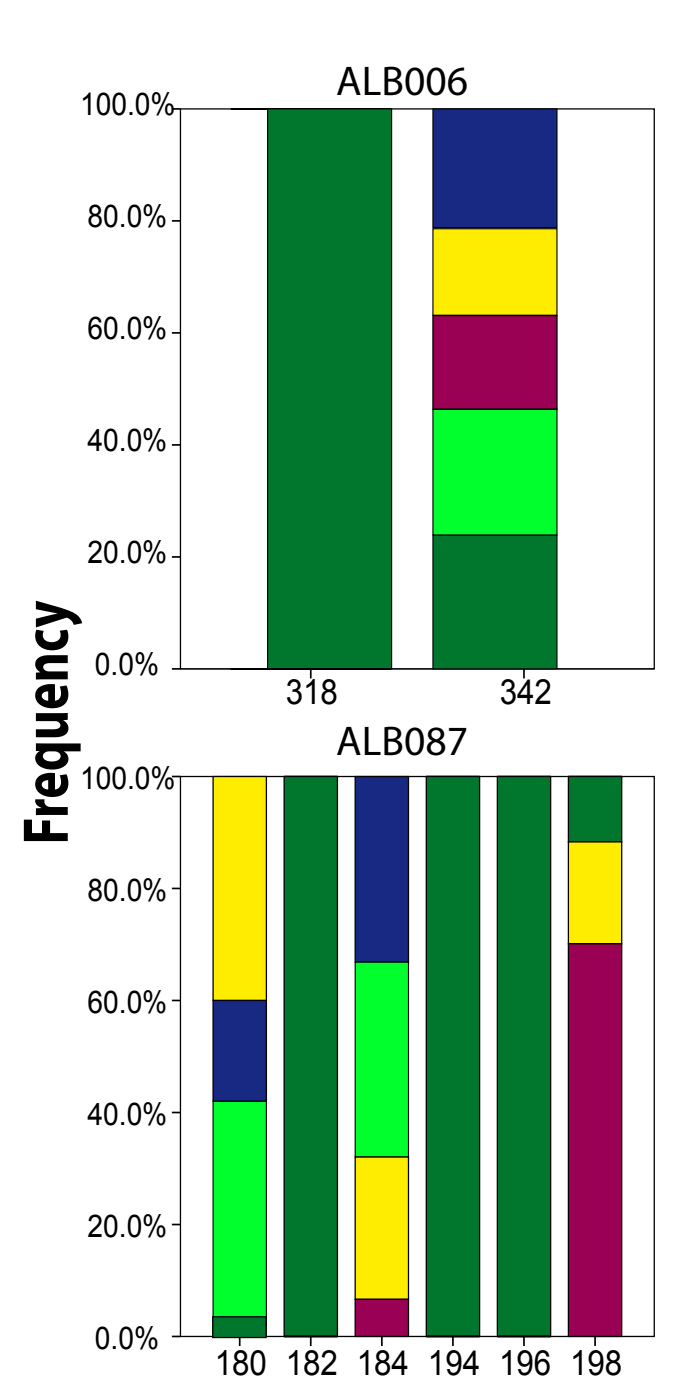

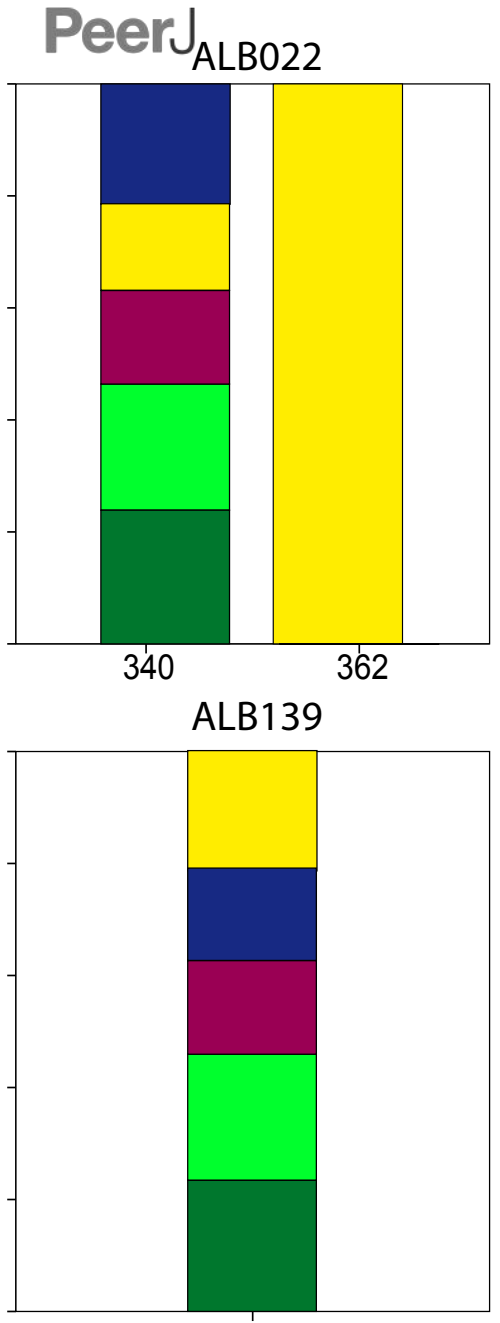

294
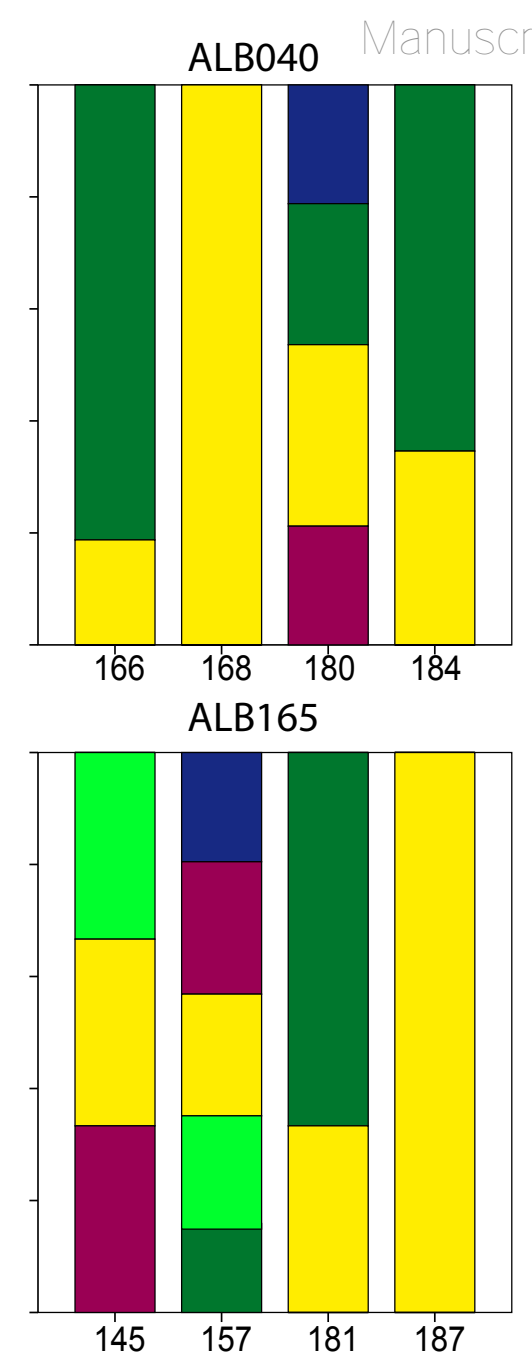

Alleles
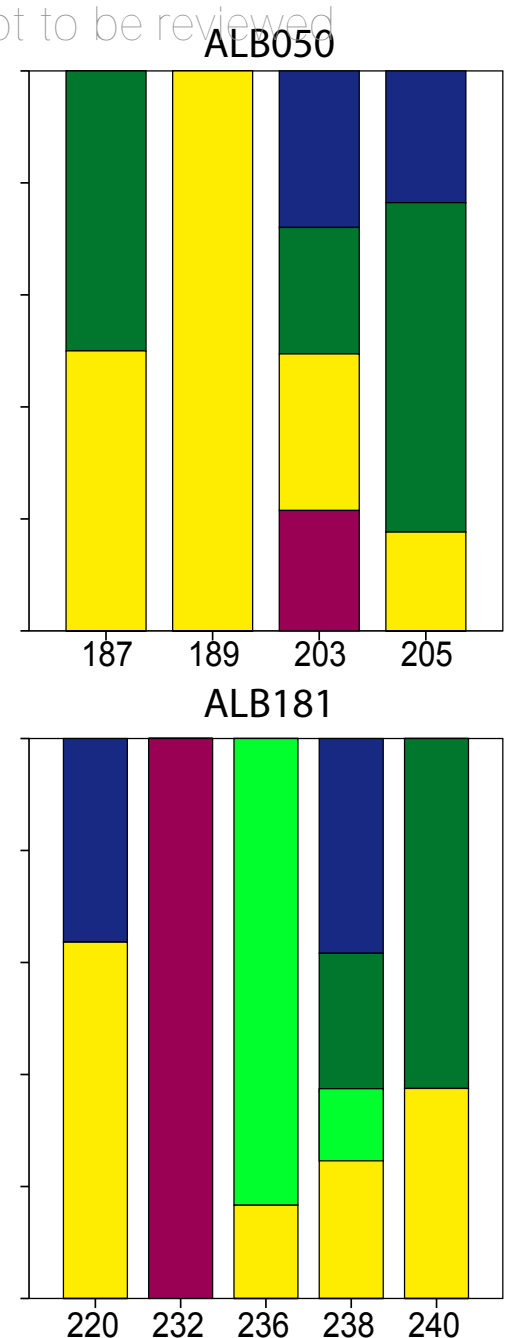

$\begin{array}{lllll}220 & 232 & 236 & 238 & 240\end{array}$
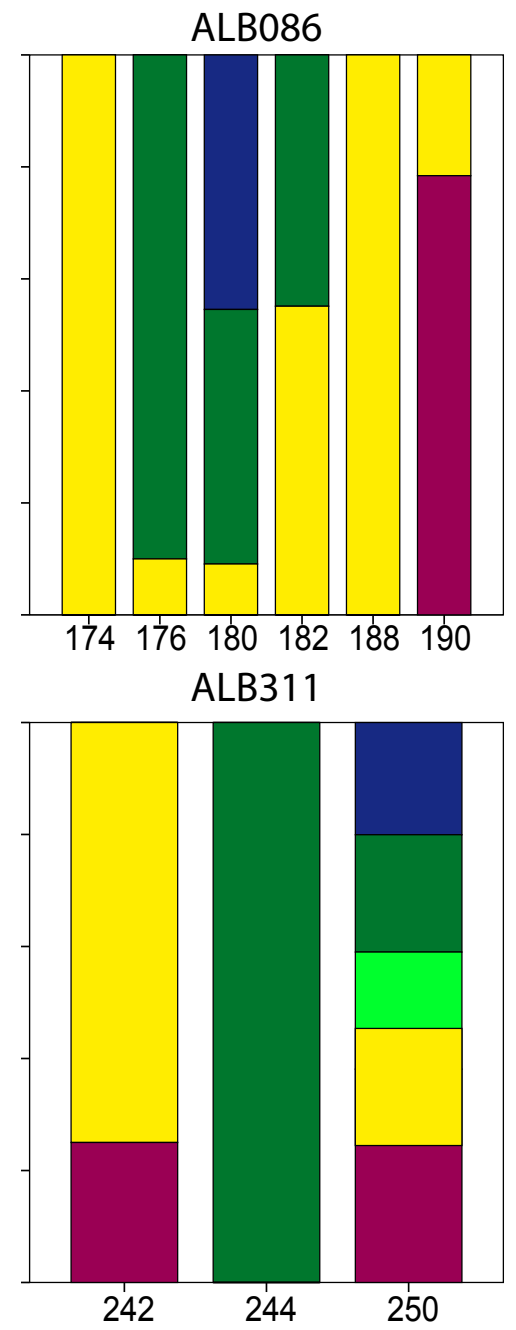

Geographical Areas

Mainland S Spain Mainland SE Spain Majorca

Minorca

Canary Islands 
Figure 3 (on next page)

Overall allelic richness of Brachypodium stacei.

Map of overall allelic richness of Brachypodium stacei across the geographic range sampled. Dark areas contain higher richness. 


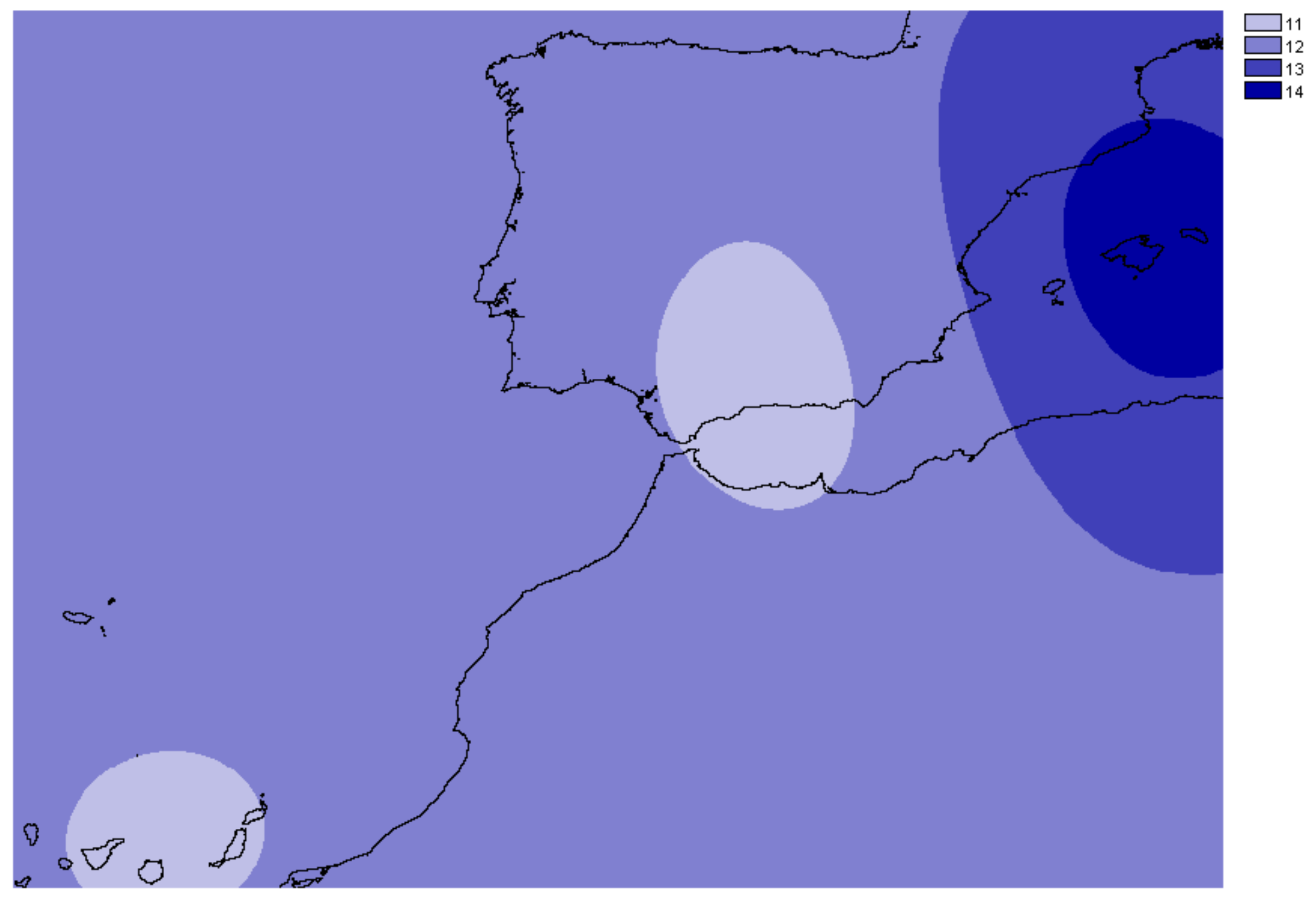


Figure 4 (on next page)

Population structure of Brachypodium stacei

Population structure of 181 individuals of Brachypodium stacei based on $10 \mathrm{nSSRs}$ and using the best assignment result $(K=2)$ retrieved by STRUCTURE (a) and by BAPS (b) with $K$ from 1 to 10 (replicated 10x) under an admixture model. Each individual is represented by a thin horizontal line divided into $K$ colored segments that represent the individual's estimated membership fractions in $K$ clusters. The different geographic areas are labelled below the graph. Abbreviations of populations follow those indicated in Table 1. 


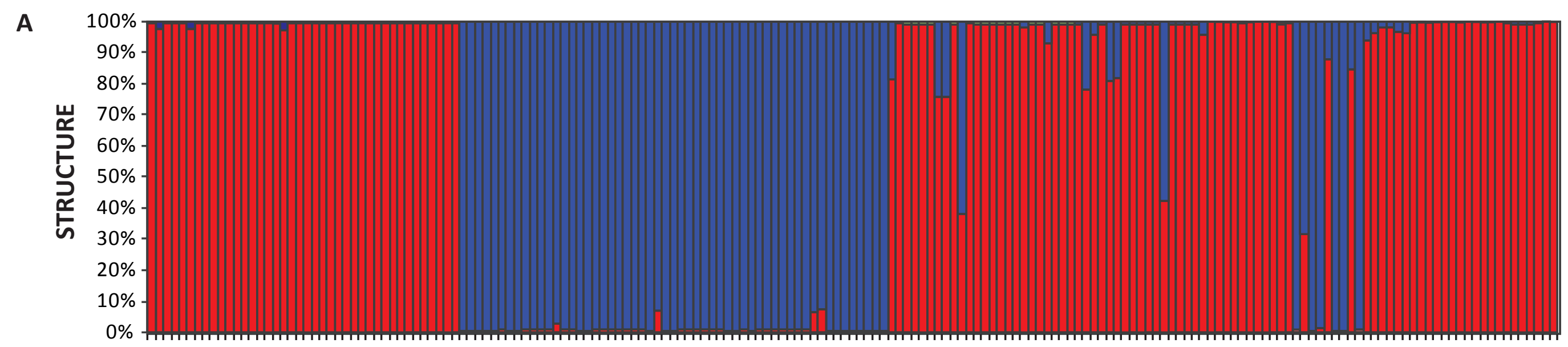

B

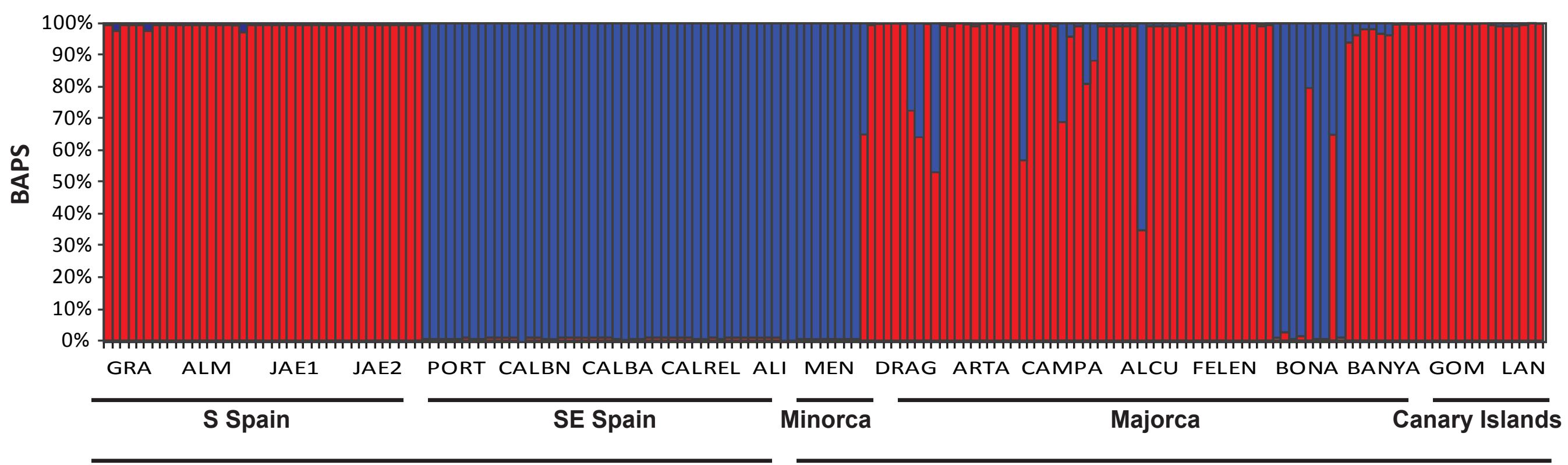

MAINLAND

ISLANDS 
Figure $\mathbf{5}$ (on next page)

Genetic relationships among Brachypodium stacei populations based on Nei's genetic distance.

Principal Coordinate analysis (PCOA) samples using the scored nSSRs markers. Percentage of explained variance of each axis is given in parentheses. Colours followed the ones depicted in Figure 4 for $K=2$. Population symbols are shown in the chart 


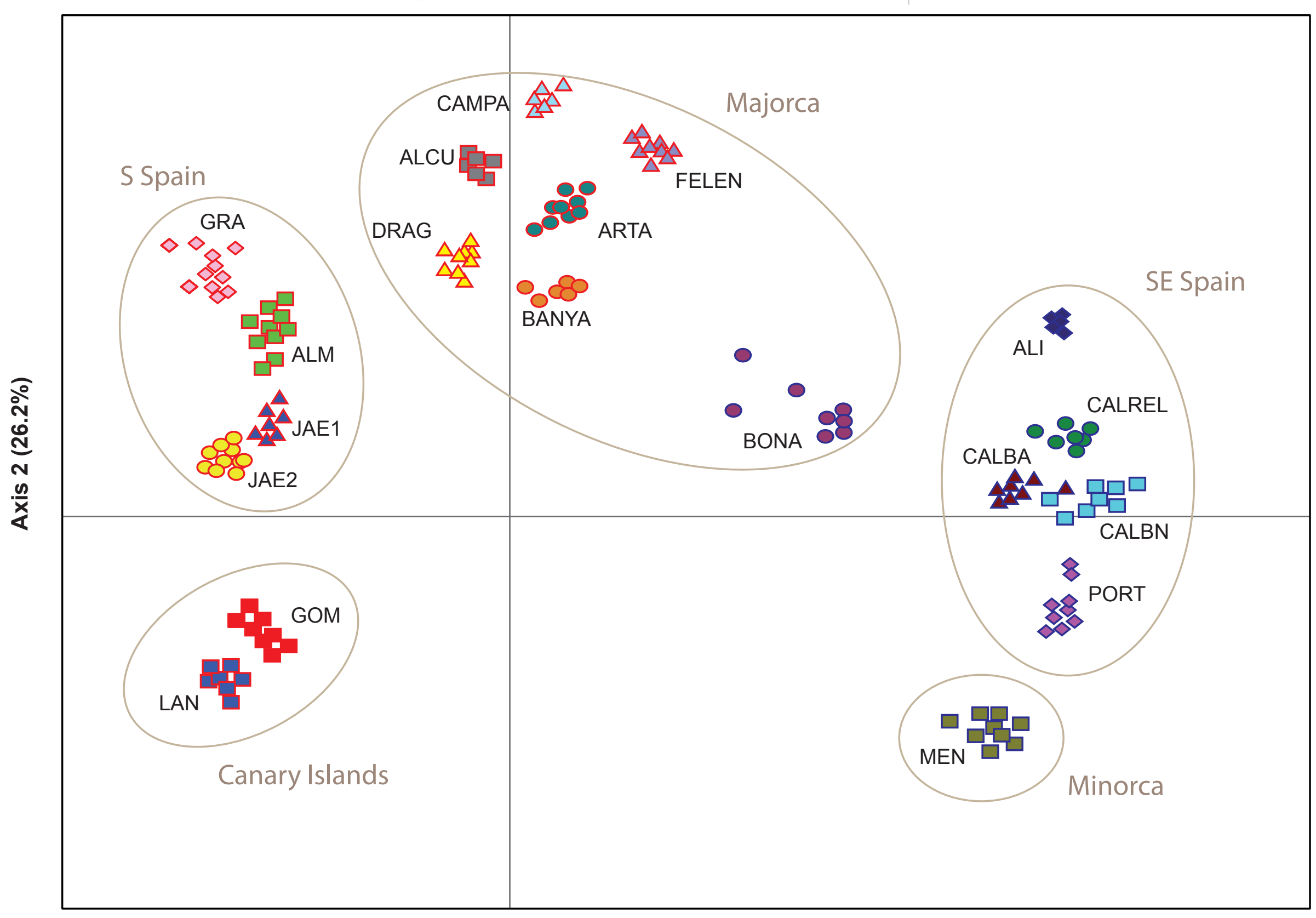

$\diamond$ GRA

$\square$ ALM

$\triangle \quad J A E 1$

○ JAE2

$\diamond \quad$ PORT

$\square$ CALBN

$\triangle$ CALBA

- CALREL

- ALI

- MEN

$\triangle$ DRAG

- ARTA

$\triangle$ CAMPA

$\square \quad$ ALCU

$\triangle$ FELEN

- BONA

- BANYA

- GOM

- LAN

Axis $1(44.3 \%)$ 


\section{Figure 6 (on next page)}

Unrooted neighbor-joining trees of Brachypodium stacei populations based on Nei's genetic distance.

Unrooted neighbor-joining tree showing relationships among the individuals collected in 19 populations. Numbers associated with branches indicate bootstrap values based on 1000 replications. Colours followed the ones depicted in Figure 4 for $K=2$. Population codes are indicated in Table 1. A) Genetic relationships among all individuals of B. stacei. B) Genetic relationships without the individuals of $B$. stacei showing admixture in STRUCTURE. Note that the Majorcan population of BONA (arrow) is grouped with SE mainland populations in both NJ trees. 


\section{Table $\mathbf{1}$ (on next page)}

Sampled populations of Brachypodium stacei sorted by geographical area.

The location, population code, number of plants genotyped $(N)$, mean observed heterozygosity $\left(H_{0}\right)$ and expected heterozygosity $\left(H_{e}\right)$, mean number of alleles $\left(N_{A}\right)$, allelic richness $\left(A_{R}\right)$, inbreeding coefficient $\left(F_{I S}\right)$, selfing rate $(s)$, and number of exclusive genotypes (\%. between parenthesis) are shown. Asterisks indicate $F_{\text {Is }}$ values deviating from HWE. 
Table 1. Sampled populations of Brachypodium stacei sorted by geographical area. The location, population code, number of plants genotyped $(N)$, mean observed heterozygosity $\left(H_{o}\right)$ and expected heterozygosity $\left(H_{e}\right)$, mean number of alleles $\left(N_{A}\right)$, allelic richness $\left(A_{R}\right)$, inbreeding coefficient $\left(\mathrm{F}_{I S}\right)$, selfing rate $(s)$, and number of exclusive genotypes $(\%$. between parenthesis $)$ are shown. Asterisks indicate $\mathrm{F}_{I S}$ values deviating from HWE.

\begin{tabular}{|c|c|c|c|c|c|c|c|c|c|c|c|}
\hline Locality & Code & $\mathbf{N}$ & Latitude (N) & Longitude (W) & $\mathbf{H}_{\mathbf{0}}$ & $\mathbf{H}_{\mathrm{e}}$ & $\mathbf{N}_{\mathbf{A}}$ & $\mathbf{A}_{\mathbf{R}}$ & $\mathbf{F}_{\text {IS }}$ & $\mathbf{s}$ & $\begin{array}{l}\text { Exclusive } \\
\text { genotypes }\end{array}$ \\
\hline \multicolumn{12}{|l|}{ Mainland (Iberian Peninsula) } \\
\hline S Spain: Granada, Moclin & GRA & 10 & $37^{\circ} 19^{\prime} 59^{\prime \prime} \mathrm{N}$ & $3^{\circ} 46^{\prime} 59^{\prime \prime} \mathrm{W}$ & 0.240 & 0.155 & 12 & 1.126 & 0.667 & 0.800 & $3(30 \%)$ \\
\hline S Spain: Almeria, Cabo de Gata & ALM & 10 & $36^{\circ} 44^{\prime} 2 " \mathrm{~N}$ & $2^{\circ} 8^{\prime} 35^{\prime \prime} \mathrm{W}$ & 0.170 & 0.102 & 11 & 1.050 & 0.0001 & 0 & $3(30 \%)$ \\
\hline S Spain: Jaen: Cazorla, Cortijos Nuevos & JAE1 & 10 & $38^{\circ} 11^{\prime} 31^{\prime \prime} \mathrm{N}$ & $2^{\circ} 48^{\prime} 14^{\prime \prime} \mathrm{W}$ & 0.120 & 0.116 & 12 & 1.176 & $0.723 *$ & 0.839 & $4(40 \%)$ \\
\hline S Spain: Jaen: Quesada, Tiscar & JAE2 & 10 & $37^{\circ} 465^{\prime \prime} \mathrm{N}$ & $3^{\circ} 11^{\prime \prime} \mathrm{W}$ & 0.200 & 0.100 & 10 & 1.000 & - & - & $1(10 \%)$ \\
\hline SE Spain: Murcia, Portman & PORT & 10 & $37^{\circ} 34^{\prime} 57^{\prime \prime} \mathrm{N}$ & $0^{\circ} 51^{\prime} 15^{\prime \prime} \mathrm{W}$ & 0.200 & 0.100 & 10 & 1.000 & - & - & $1(10 \%)$ \\
\hline SE Spain: Murcia: Calblanque & $\begin{array}{l}\text { CALB } \\
\mathrm{N}\end{array}$ & 10 & $37^{\circ} 35^{\prime} 59^{\prime \prime} \mathrm{N}$ & $0^{\circ} 45^{\prime} 29 " \mathrm{~W}$ & 0.140 & 0.108 & 14 & 1.246 & $0.526^{*}$ & 0.689 & $4(40 \%)$ \\
\hline SE Spain: Murcia: Cobaticas & $\begin{array}{l}\text { CALB } \\
\text { A }\end{array}$ & 10 & $37^{\circ} 35^{\prime} 59^{\prime \prime} \mathrm{N}$ & $0^{\circ} 45^{\prime} 30^{\prime \prime} \mathrm{W}$ & 0.110 & 0.105 & 15 & 1.339 & $0.617 *$ & 0.763 & $5(50 \%)$ \\
\hline SE Spain: Murcia, Cala Reona & $\begin{array}{l}\text { CALRE } \\
\mathrm{L}\end{array}$ & 10 & $37^{\circ} 36^{\prime} 56^{\prime \prime} \mathrm{N}$ & $0^{\circ} 42^{\prime} 56^{\prime \prime} \mathrm{W}$ & 0.030 & 0.009 & 13 & 1.239 & $0.520^{*}$ & 0.684 & $5(50 \%)$ \\
\hline SE Spain: Alicante, Cano La Nao & ALI & 5 & $38^{\circ} 45^{\prime} 22^{\prime \prime} \mathrm{N}$ & $0^{\circ} 13^{\prime} 8^{\prime \prime} \mathrm{E}$ & 0.300 & 0.150 & 10 & 1.000 & - & - & $1(20 \%)$ \\
\hline \multicolumn{12}{|l|}{ Balearic (Gymnesic) Islands } \\
\hline Minorca: Es Mercadal, Toro & MEN & 10 & $39^{\circ} 59^{\prime} 6 " \mathrm{~N}$ & $4^{\circ} 6^{\prime} 47^{\prime \prime} \mathrm{E}$ & 0.240 & 0.173 & 13 & 1.203 & $0.386^{*}$ & 0.556 & $3(30 \%)$ \\
\hline Majorca: Sa Dragonera, Gambes & DRAG & 10 & $39^{\circ} 35^{\prime} 13^{\prime \prime} \mathrm{N}$ & $2^{\circ} 19^{\prime} 37^{\prime \prime} \mathrm{E}$ & 0.111 & 0.154 & 16 & 1.428 & $0.916^{*}$ & 0.956 & $5(50 \%)$ \\
\hline Majorca: Arta, Peninsula de Llevant & ARTA & 10 & $39^{\circ} 44^{\prime} 10^{\prime \prime} \mathrm{N}$ & $3^{\circ} 20^{\prime} 6^{\prime \prime} \mathrm{E}$ & 0.210 & 0.128 & 12 & 1.126 & $0.666^{*}$ & 0.800 & $3(30 \%)$ \\
\hline Majorca: Campanet, Coves & $\begin{array}{l}\text { CAMP } \\
\text { A }\end{array}$ & 10 & $39^{\circ} 47^{\prime} 31^{\prime \prime} \mathrm{N}$ & $2^{\circ} 58^{\prime} 12^{\prime \prime} \mathrm{E}$ & 0.130 & 0.138 & 14 & 1.434 & $0.486^{*}$ & 0.654 & $6(60 \%)$ \\
\hline Majorca: Alcudia, Punta Negra & ALCU & 10 & $39^{\circ} 52^{\prime} 48^{\prime \prime} \mathrm{N}$ & $3^{\circ} 10^{\prime} 41^{\prime \prime} \mathrm{E}$ & 0.140 & 0.108 & 14 & 1.200 & 0.0001 & 0 & $2(20 \%)$ \\
\hline Majorca: Felenitx, San Salvador & FELEN & 10 & $39^{\circ} 27^{\prime} 4 " \mathrm{~N}$ & $3^{\circ} 11^{\prime} 17^{\prime \prime} \mathrm{E}$ & 0.130 & 0.109 & 14 & 1.200 & 0.250 & 0.400 & $4(40 \%)$ \\
\hline Majorca: Petra, Bonany & BONA & 10 & $39^{\circ} 35^{\prime} 38^{\prime \prime} \mathrm{N}$ & $3^{\circ} 5^{\prime} 10^{\prime \prime} \mathrm{E}$ & 0.290 & 0.391 & 23 & 1.992 & $0.385^{*}$ & 0.565 & $9(90 \%)$ \\
\hline Majorca: Banyalbufar, Ses Animes & $\begin{array}{l}\text { BANY } \\
\text { A }\end{array}$ & 6 & $39^{\circ} 41^{\prime} 6^{\prime \prime} \mathrm{N}$ & $2^{\circ} 30^{\prime} 36^{\prime \prime} \mathrm{E}$ & 0.167 & 0.239 & 15 & 1.496 & $0.825^{*}$ & 0.904 & $6(100 \%)$ \\
\hline \multicolumn{12}{|l|}{ Canary Islands } \\
\hline Gomera: Agulo & GOM & 10 & $28^{\circ} 10^{\prime} 59^{\prime \prime} \mathrm{N}$ & $17^{\circ} 10^{\prime} 59^{\prime \prime} \mathrm{W}$ & 0.150 & 0.118 & 11 & 1.076 & $1.000^{*}$ & 1.998 & $2(20 \%)$ \\
\hline Lanzarote: Teguise & LAN & 10 & $29^{\circ} 4^{\prime} 1 " \mathrm{~N}$ & $13^{\circ} 31^{\prime} 1^{\prime \prime} \mathrm{W}$ & 0.230 & 0.136 & 11 & 1.096 & $1.000^{*}$ & 1.999 & $2(20 \%)$ \\
\hline
\end{tabular}




\section{5}

6

7

8

9

10

11

12

13

14

15

16

17 


\section{Table 2 (on next page)}

Hardy Weinberg Exact Tests.

Results of the Hardy Weinberg Exact Tests retrieved by GENEPOP for 19 populations of Brachypodium stacei. P-value associated with the null hypothesis of random union of gametes (or '-' if no data were available, or only one allele was present) estimated with a Markov chain algorithm (Guo and Thompson, 1992) and the standard error (S.E.) of this estimate. 
2 Table 2. Results of the Hardy Weinberg Exact Tests retrieved by GENEPOP for 19 populations of Brachypodium stacei. $P$-value associated with the null hypothesis of random union of gametes (or '-' if no data were available, or only one allele was present) estimated with a Markov chain algorithm (Guo and Thompson, 1992) and the standard error (S.E.) of this estimate.

\begin{tabular}{lcc}
\hline Population & $\boldsymbol{P}$-value & SE \\
\hline GRA & 0.0519 & 0.0011 \\
ALM & - & \\
JAE1 & 0.0259 & 0.0007 \\
JAE2 & - & \\
PORT & - & \\
CALBN & 0.0077 & 0.0009 \\
CALBA & 0.0007 & 0.0001 \\
CALREL & 0.0249 & 0.0006 \\
ALI & - & \\
MEN & 0.1016 & 0.0015 \\
DRAG & 0 & 0 \\
ARTA & 0.053 & 0.0012 \\
CAMPA & 0.0361 & 0.0014 \\
ALCU & - & \\
FELEN & 0.0508 & 0.0028 \\
BONA & 0 & 0 \\
BANYA & 0 & 0 \\
GOM & 0.0515 & 0.0012 \\
LAN & 0.0096 & 0.0005 \\
\hline
\end{tabular}




\section{Table 3(on next page)}

Characteristics and genetic diversity statistics of the nuclear microsatellite markers used in the genetic study of Brachypodium stacei.

For each locus, the total number of alleles $(\mathrm{Na})$, mean expected heterozygosity $(\mathrm{He})$, mean observed heterozygosity $(\mathrm{Ho})$, and the fixation index $\left(\mathrm{F}_{\mathrm{IS}}\right)$ obtained from the 181 studied individuals are shown. 
1 Table 3. Characteristics and genetic diversity statistics of the nuclear microsatellite markers used in the genetic study of 2 Brachypodium stacei. For each locus, the total number of alleles $(\mathrm{Na})$, mean expected heterozygosity $(\mathrm{He})$, mean observed 3 heterozygosity (Ho), and the fixation index $\left(\mathrm{F}_{\mathrm{IS}}\right)$ obtained from the 181 studied individuals are shown.

\begin{tabular}{|c|c|c|c|c|c|}
\hline Locus & Repeat motif & $\mathbf{N}_{\mathrm{a}}$ & $\mathbf{H}_{\mathrm{e}}$ & $\mathbf{H}_{\mathbf{o}}$ & $\mathbf{F}_{\text {IS }}$ \\
\hline ALB006 & (GT)15 & 2 & 0.016 & 0.016 & 0.003 \\
\hline ALB022 & (CT)11 & 2 & 0.035 & 0.005 & 0.848 \\
\hline ALB040 & (CTT) 8 & 4 & 0.129 & 0.047 & 0.632 \\
\hline$A L B 050$ & $(\mathrm{GT}) 15$ & 4 & 0.122 & 0.032 & 0.717 \\
\hline ALB086 & $(\mathrm{AAG}) 7$ & 6 & 0.119 & 0.058 & 0.486 \\
\hline ALB087 & $(\mathrm{AGC}) 7$ & 6 & 0.145 & 0.032 & 0.758 \\
\hline$A L B 139$ & $(\mathrm{AGA}) 7$ & 1 & 0.000 & 0.000 & 0 \\
\hline$A L B 165$ & (ATA) 12 & 4 & 0.066 & 0.049 & 0.298 \\
\hline$A L B 181$ & $(\mathrm{AC}) 9$ & 5 & 0.049 & 0.037 & 0.253 \\
\hline ALB311 & $(\mathrm{GA}) 6$ & 3 & 0.025 & 0.026 & -0.069 \\
\hline
\end{tabular}

6

7

8

9

10

11 


\section{Table 4 (on next page)}

AMOVA of Brachypodium stacei.

Analysis of molecular variance (AMOVA) for 19 populations of Brachypodium stacei. 
1 Table 4. Analysis of molecular variance (AMOVA) for 19 populations of Brachypodium stacei.

\begin{tabular}{|c|c|c|c|c|}
\hline & Source of variance & d.f. & $\begin{array}{c}\text { Variance } \\
\text { components }\end{array}$ & $\%$ Variance \\
\hline \multicolumn{5}{|l|}{ All populations } \\
\hline & Among populations & 18 & 1.011 & 74.88 \\
\hline & Within populations & 343 & 0.339 & 25.12 \\
\hline \multicolumn{5}{|c|}{$\begin{array}{l}\text { Between genetic groups } \\
\text { defined by STRUCTURE } \\
\text { and BAPS }(K=2)\end{array}$} \\
\hline & Among groups & 1 & 0.370 & 24.05 \\
\hline & $\begin{array}{l}\text { Among populations within } \\
\text { groups }\end{array}$ & 17 & 0.831 & 53.94 \\
\hline & Within populations & 343 & 0.339 & 22.01 \\
\hline \multicolumn{5}{|c|}{ Mainland vs. islands } \\
\hline & Among groups & 1 & 0.109 & 7.77 \\
\hline & $\begin{array}{l}\text { Among populations within } \\
\text { groups }\end{array}$ & 17 & 0.954 & 68.04 \\
\hline & Within populations & 343 & 0.339 & 24.19 \\
\hline \multicolumn{5}{|c|}{$\begin{array}{l}\text { Within mainland } \\
\text { populations (S Spain vs SE } \\
\text { Spain) }\end{array}$} \\
\hline & Among groups & 1 & 0.831 & 46.41 \\
\hline & $\begin{array}{l}\text { Among populations within } \\
\text { groups }\end{array}$ & 7 & 0.752 & 41.99 \\
\hline & Within populations & 161 & 0.207 & 11.60 \\
\hline \multicolumn{5}{|c|}{$\begin{array}{l}\text { Within island populations } \\
\text { (Balearic islands vs Canary } \\
\text { islands) }\end{array}$} \\
\hline & Among groups & 2 & 0.448 & 32.26 \\
\hline & $\begin{array}{l}\text { Among populations within } \\
\text { groups }\end{array}$ & 7 & 0.486 & 34.97 \\
\hline & Within populations & 182 & 0.455 & 32.77 \\
\hline
\end{tabular}

